\title{
REGRAS E PRINCÍPIOS: POR UMA DISTINÇÃO NORMOTEORÉTICA
}

\author{
Álvaro Ricardo de Souza Cruz"
}

RESUMO: O autor aborda a distinção entre regras e princípios a partir de uma distinção normoteorética, expondo as diversas teorias em um esforço de não cair na armadilha do sincretismo impróprio do emprego de teorias incompatíveis entre si.

O debate atual sobre a "teoria dos princípios" e a distinção das espécies normativas entre princípios e as regras devem ser atribuídos a Ronald Dworkin. Desde a edição do texto "O modelo de regras I" o arcabouço hermenêutico positivista sofreu um enorme abalo. $\mathrm{O}$ edifício de uma hermenêutica tributária do aguilhão semântico, ou seja, aferrada ao exame do texto em termos "convencionalistas", "pragmatistas", "realistas" ou meramente positivistas apresentou rachaduras insanáveis.

Desse modo, se vamos abordar a questão de uma distinção entre regras e princípios, desde já deixamos claro que estamos examinando o problema sob o ponto de vista de diferentes espécies de normas jurídicas, o que, de plano, afasta um conjunto

* Procurador da República em Minas Gerais Mestre em Direito Econômico e Doutor em Direito Constitucional pela UFMG, Professor da Graduação e da Pós-Graduação da Pontifícia Universidade Católica de Minas Gerais. amplo que a doutrina usualmente designa como "princípios" e que, na verdade, são postulados jurídicos, ou seja, tanto condições de possibilidade para o conhecimento quanto condições destrancendentalizadas para o reconhecimento da validade desse conhecimento sistema jurídico. Assim, postulados devem ser entendidos como elementos sem os quais soçobram a coerência, a integridade e a consistência do Direito, sob o ponto de vista propedêutico de um paradigma científico específico. Desse modo, a "supremacia da Constituição"1 " "a unidade", "a concordância prática", "a subsidiariedade" dentre outros, devem ser compreendidos como postulados jurídicos e, por conseguinte, exorbitam o interesse desse capítulo que vai

\footnotetext{
${ }^{1}$ Desde que essa supremacia não seja entendida em termos positivistas, ou seja, que a mesma pressupunha a abertura da identidade do sujeito constitucional. Nesse sentido, sugerimos a leitura de nosso artigo "Poder Constituinte e Patriotismo Constitucional".
} 
se ater exclusivamente ao exame do campo de normas jurídicas.

Feitas tais considerações, haveria de se perguntar qual a utilidade de examinar a teoria dos princípios quase cinqüenta anos depois da contribuição de Dworkin. A resposta vem de imediato: pelo fato de o modo de operar o Direito no Brasil ser ainda claramente ligado ao que ele denominava “aguilhão semântico", isso é, a uma forma convencionalista de operação do Direito. Tal constatação vem, não somente do cotidiano de nossos juízes, procuradores, promotores e advogados, mas também na multiplicação de textos normativos que se aferrram à idéia iluminista de que "uma boa lei" possa resolver nossos problemas. Desse modo, temas como os do requisito da "repercussão geral para o conhecimento de recursos extraordinários" e da "súmula vinculante", a distinção entre "atos administrativos vinculados e discricionários”, a profusão de mudanças legislativas na tramitação dos recursos no Código de Processo Civil, nada mais são do que reminiscências de uma ciência do Direito ligada à filosofia da consciência.

Portanto, a teoria dos princípios de Dworkin descortina no Direito a perspectiva de uma hermenêutica crítica e pós-positivista. Logo, precisamos levar a sério a questão da superação dos parâmetros hermenêuticos dos paradigmas jurídico e filosófico anteriores. Soma-se a essa constatação o fato de que há, na doutrina, uma profusão de conceitos e classificações sobre regras e princípios ${ }^{2}$.

${ }^{2}$ A distinção entre princípios e regras virou moda. Os trabalhos de direito público tratam da distinção, com raras exceções, como se ela de tão óbvia, dispensasse maiores aprofundamentos. A separação entre as espécies normativas como que ganha foros de unanimidade. E a unanimidade termina por semear não
Assim, vamos expor algumas dessas teorias de maneira a deixar clara nossa visão sobre o tema, tendo em vista um esforço de não cair na armadilha cada vez mais comum na doutrina brasileira: o sincretismo impróprio do emprego de teorias incompatíveis entre si.

Desse modo, percebemos, mesmo com o risco inerente de reducionismo a qualquer classificação, que o estudo da principiologia jurídica assume três paradigmas distintos: o clássico, o moderno e o contemporâneo. $\mathrm{O}$ paradigma clássico ignora ou no máximo vislumbra um papel secundário aos princípios jurídicos. O paradigma moderno assume a juridicidade dos mesmos e os coloca em posição de destaque no ordenamento jurídico em função de sua abstração, generalidade, abertura textual $^{3}$. Em síntese, os princípios

mais o conhecimento crítico das espécies normativas, mas a crença de que elas são dessa maneira, e pronto. (ÁVILA, Humberto. Teoria dos princípios. Da definição à aplicação dos princípios jurídicos. 2. ed. São Paulo: Malheiros, 2003, p. 18).

${ }^{3}$ Canotilho resume os critérios de distinção entre regras e princípios nesse paradigma: a) Grau de abstracção: os princípios são normas com um grau de abstracção relativamente elevado; de modo diverso, as regras possuem uma abstracção relativamente reduzida. B) Grau de determinabilidade na aplicação do caso concreto: os princípios, por serem vagos e indeterminados, carecem de mdediações concretizadoras, enquanto as regras são susceptiveis de aplicação directa. C) Grau de fundamentalidade no sistema das fontes de direito: os princípios são normas de natureza ou com um papel fundamental no ordenamento jurídico devido à sua posição hierárquica no sistema das fontes (ex. princípios constitucionais) ou á sua importância estruturante dentro do sistema jurídico (ex. princípio do Estado de Direito). D) 'Proximidade da idéia de direito: os princípios são 'standards' juridicamente vinculantes radicados nas exigências de 'justiça' (Dworkin) ou na 'idéia de direito' (Larenz); as regras podem ser normas vinculativas com um conteúdo meramente funcional. E) Natureza normogenética; os princípios são fundamento de regras, isto é, são normas que estão na base ou constituem a ratio de regaras jurídicas, desempenhando, por isso, uma função normogenética fundamentante. (CANOTILHO, J.J. Gomes. Direito constitucional e Teoria da Constituição. Coimbra; Almedina, 1997, p. 1034/1035). 
se tornam fundamento axiológico do Direito. Por fim, as correntes contemporâneas se esforçam por reafirmar sua distinção para com as regras a partir dos ganhos do giro lingüístico, no sentido de construção de bases pós-positivistas para o Direito. Cumpre, pois, o exame sintético de cada uma delas de modo a demonstrar que nossa doutrina, de modo geral, os emprega de forma assistemática e não científica. Cumpre também verificar se as teorias contemporâneas são suficientemente racionais como suporte teórico para tal distinção, de modo a evitarmos que a Ciência caia em uma fundamentação dogmática.

Nesse sentido, o interesse remanescente sobre o paradigma clássico só ganha alguma relevância se considerarmos que a maior parte do ensino jurídico e o modo de produção do Direito no Brasil ainda são preponderantemente positivistas. Desse modo, a hermenêutica jurídica evolui de uma completa indiferença em relação a eles até a admissão de sua cogência normativa em caráter subsidiário.

O paradigma do Estado Liberal de Direito conformou a atividade jurisdicional mediante uma divisão qualitativa dos poderes, de forma que o ato legislativo fosse entendido como um provimento estatal fruto da vontade "geral" ou da maioria, em um contexto de uma democracia representativa com suporte no pensamento de Locke e de Montesquieu, e o ato jurisdicional, um ato de cognição da legalidade posta.

ODireito, enquanto ordenamento, ao estabelecer limites universais preponderantemente negativos (não furtar, não matar, etc., como traduzido, por exemplo, por Fichte) é, então, visto como o conjunto de regras que delimitam os espaços de liberdade de um indivíduo as linhas demarcatórias da fronteira em que termina a liberdade de um indivíduo e em que se inicia a liberdade de outro. Assim, o paradigma do Estado de Direito ao limitar o Estado à legalidade, ou seja, ao requerer que a lei discutida e aprovada pelos representantes da "melhor sociedade" autorize a atuação de um Estado mínimo, restrito ao policiamento para assegurar a manutenção do respeito àquelas fronteiras anteriormente referidas e, assim, garantir o livre jogo da vontade dos atores sociais individualizados, vedada a organização corporativo-coletiva, configura, aos olhos dos homens de então, um ordenamento jurídico de regras gerais e abstratas, essencialmente negativas, que consagram os direitos individuais ou de $1^{\text {a }}$ geração, uma ordem jurídica liberal clássica. É claro que sob este primeiro paradigma constitucional, $\mathrm{o}$ do Estado de Direito, a questão da atividade hermenêutica do juiz só poderia ser vista como uma atividade mecânica, resultado de uma leitura direta dos textos que deveriam ser claros e distintos, e a interpretação algo a ser evitado até mesmo pela consulta ao legislador na hipótese de dúvidas do juiz diante de textos obscuros e intrincados. Ao juiz é reservado o papel de mera "bouche de la loi". ${ }^{4}$

A hermenêutica limitava-se ao esforço sintático e semântico dos textos jurídicos a partir de métodos de dedução e subsunção, típicos da conhecida proposta de Savigny ${ }^{5}$.

${ }^{4}$ CARVALHO NETO, Menelick. Hermenêutica Constitucional sob o paradigma do Estado Democrático de Direito, p. 25/44, p. 33/34, sem destaque no original.

${ }^{5}$ Em contraposição com o primado do costume que defenderá ulteriormente, Savigny equipara ainda no seu curso o Direito positivo ao Direito Legislado. Todavia, a legislação acontece no tempo e isto conduz "à concepção de uma história do Direito que estreitamente se conjuga com a história do Estado e a história dos povos, visto que a legislação é uma actividade do Estado" (p. 17). Além disso, SAVIGNY distingue uma elaboração interpretativa (sistemática) do Direito. Como objecto da interpretação aponta ele "a reconstrução do pensamento que é expresso na lei, na medida de"se colocar na posição do legislador e deixar que se formem, por esse artifício, os respectivos ditames". Para esse fim a interpretação 
A concepção iluminista de um Direito racional trazia consigo a visão da generalidade e da harmonia das regras jurídicas, como contraponto à pluralidade de fontes normativas e de jurisdições típicas do Antigo Regime. Logo, o intérprete navegava em um lago de águas mansas de regras. O Direito era um todo compacto da qual nenhuma relação humana poderia ter escapado do "gênio" do legislador.

Nesse contexto, os princípios jurídicos eram absorvidos como expressão de cunho político do legislador, típico do constitucionalismo do século XIX, no qual, seja pelas tradições revolucionárias francesas de oposição aos desmandos do judiciário, seja pela ausência de uma formação democrática como na Prússia e na recém-criada Alemanha, as Constituições eram vistas muito mais por seu caráter de documento político, tal como na "Declaração Universal dos Direitos do homem e do cidadão", do que por sua juridicidade, tal como se via na América desde Madison v. Marbury (1803).

Por conseguinte, não é possível falar que a tese de normas programáticas nascidas no princípio do século passado tenha surgido tão-somente como forma de se negar eficácia aos direitos sociais e coletivos. Essa reação contrária ao surgimento de um novo constitucionalismo, dito social, tem supedâneo em práticas constitucionais muito mais antigas.

Todavia, as dificuldades de encontrar-se sempre a priori a norma que se adequaria

precisa de três elementos: "um elemento lógico, um elemento gramatical e um elemento histórico” (p. 9). (LARENZ, Karl. Metodologia da Ciência do Direito. Tradução de José Lamego. 3. ed. Lisboa: Fundação Calouste Gulbekian, 1997, p. 10-11). perfeitamente ao caso concreto, típico ainda de uma maneira de pensar ligada à filosofia da consciência, não tardaram a mostrar suas mazelas e dificuldades. De certo, uma interpretação literal, declarativa, gramatical, mesmo auxiliada pelos "elementos sistemático, lógico e finalístico" puderam fazer face aos desafios do Direito.

Desse modo, constataram-se duas formas de reação na teoria do Direito. De um lado, as antinomias e anomias, que eram desde há muito conhecidas, pelo menos desde o tempo da jurisdição canônica e, mesmo antes, com os glosadores, passaram a admitir o emprego subsidiário da analogia, dos costumes e dos princípios gerais do Direito. A simples constatação da nossa Lei de Introdução ao Código Civil exemplifica o raciocínio acima. E, de outro, a tese da discricionariedade judicial, decorrente da crença que a jurisdição não poderia conduzir a uma única resposta, passa a difundir-se, em especial pelo trabalho de Kelsen ${ }^{6}$.

A concepção de um Direito voltado para um modo de operar legalista, destituído de qualquer reflexão sobre os detalhes do caso e que se apresentava galvanizado pelo

${ }^{6}$ A teoria usual da interpretação quer fazer crer que a lei, aplicada ao caso concreto, poderia fornecer, em todas as hipóteses, apenas uma única solução correcta (ajustada) e que a justeza (correção) jurídico-positiva desta decisão é fundada na própria lei. Configura o processo desta interpretação como se se tratasse tão-somente de um acto intelectual de classificação e de compreensão, como se o órgão aplicador do Direito apenas tivesse que pôr em acção o seu entendimento (razão), mas não a sua vontade, e como se, através de uma pura actividade de intelecção, pudesse realizar-se, entre as possibilidades que se apresentam, uma escolha que correspondesse ao Direito positivo, uma escolha correcta (justa) no sentido do direito positivo.(KELSEN, Hans. Teoria Pura do Direito. Tradução de João Baptista Machado. 4. ed. Coimbra: Armênio Amado, 1979, p. 467). 
apego à legalidade estrita, mostrou toda sua insuficiência pela inércia/colaboração do Judiciário alemão durante os horrores de Auschwitz. Toda a tradição do direito romano-germânico de observância dos "ditames" da lei e de procura pela "vontade do legislador" se chocava diante da cumplicidade do Reichsgericht diante dos arbítrios e atrocidades nazistas.

Será sob esse contexto que perceberemos o surgimento de novos "ventos" no constitucionalismo, em especial o surgimento da tópica de Viehweg e, no tocante à teoria dos princípios, o nascimento de uma nova forma de abordagem. Agora, tanto positivistas quanto os adeptos de um jusnaturalismo renascido se posicionavam favoravelmente à juridicidade dos princípios. E, mais ainda, concediam-lhes uma posição de primazia dentro do ordenamento jurídico.

A primeira teoria é aquela que identifica os princípios com normas gerais ou generalíssimas de um sistema. Desde o início do século, autores como Del Vechio e Bobbio tentaram compreender os princípios jurídicos como fruto de processos de generalização operados pela Ciência do Direito. Del Vechio afirmou, por exemplo, que os princípios gerais são descobertos por intermédio da generalização crescente de outras normas do ordenamento jurídico (Del Vechio, 1948:51), ou seja, pela indução podemos partir de regras que regulam situações específicas e inferir daí princípios superiores a essas regras, que passam a poder ser aplicados dedutivamente. Já Bobbio afirmou que os princípios gerais do direito são, tão-somente, "normas fundamentais ou generalíssimas do sistema, as normas mais gerais". ?

A concepção pela qual os princípios pudessem ser deduzidos por meio da

${ }^{7}$ GALUPPO, Igualdade e Diferença, p. 170. generalização de regras, a despeito de lugar comum entre os operadores do Direito no Brasil, vem, desde a década de 1950 , sendo questionada. Josef Esser, nessa oportunidade, já constatara que a maior ou menor generalidade dos princípios em relação às regras não poderia ser um critério racional de distinção, uma vez que nem todo princípio se origina de um processo de generalização.

Contudo, não são poucos os autores tributários dessa visão, tanto na doutrina pátria quanta na alienígena. Em suas variantes, os princípios assumem a condição metanormativa por meio da percepção de algumas características que os definiriam: desse modo, uns optam pelo fato que os princípios exprimiriam os valores retores do ordenamento jurídico; outros vêem seu traço distintivo no seu maior grau de abstração; outros derivam seu raciocínio em torno do que entendem ser uma maior indeterminação da sua tipicidade (fatie specie). No entanto, seja qual for a tese, todos passam a sustentar um papel de proeminência dos princípios no ordenamento jurídico, chegando alguns a entender haver uma hierarquia entre eles e as regras no qual os princípios estariam em posição privilegiada.

Quando se refere à ligação dos princípios com os valores, não se pode esquecer da contribuição de Canaris. A seu ver, os princípios conteriam um conteúdo axiológico puro e se distinguiriam das regras porque dependeriam destas para sua concretização. Desse modo, eles passam a ser entendidos como normas que dariam fundamento a todo o ordenamento jurídico.

Com a caracterização do sistema como ordem teleológica ainda não foi, contudo, dada resposta à segunda pergunta essencial: a dos 
elementos constitutivos nos quais se tornem perceptíveis a unidade interna e a adequação da ordem jurídica. No entanto, ficou já esclarecido que se deve tratar de valores, ainda que isso não possa constituir a resposta final, pois se mantém a questão mais vasta de que valores se trata: todos ou apenas alguns? (...) Mas isso significa que, na descoberta do sistema teleológico, não se pode ficar pelas "decisões de conflitos" e dos valores singulares, antes se devendo avançar até aos valores fundamentais mais profundos, portanto até aos princípios gerais duma ordem jurídica; trata-se, assim, de apurar, por detrás da lei e da ratio legis, a ratio iuris determinante. Pois só assim podem os valores singulares libertar-se do seu isolamento aparente e reconduzir-se à procurada conexão "orgânica" e só assim se obtém aquele grau de generalização sobre o qual a unidade da ordem jurídica, no sentido acima caracterizado, se torna perceptível. O sistema deixa-se, assim, definir como uma ordem axiológica ou teleológica de princípios gerais de Direito, na qual o elemento de adequação valorativa se dirige mais à caracterização de ordem teleológica e o da unidade interna à característica dos princípios gerais. ${ }^{8}$

Já destacamos anteriormente o problema de traduzir-se um comando normativo de caráter deontológico em um plexo de ordens meramente teleológicas. Logo, consideramos repetitivo reproduzirmos essa crítica, eis que ninguém nega que o Direito como subsistema social reproduz valores todo o tempo. A questão é que sua forma de operar não pode se dar em torno do emprego de valores, sob pena de perdermos com isso qualquer possibilidade de legitimidade do mesmo. Preferimos anotar que o traço de diferenciação entre as espécies normativas em

8 CANARIS, Claus-Wilhelm. Pensamento sistemático e conceito de sistema na ciência do Direito. 3. ed. Introdução e tradução de A. Menezes Cordeiro. Lisboa: Fundação Calouste Gulbekian, 2002, p. 76/78. torno de seu caráter axiológico é insuficiente por uma outra razão e, para tanto, um exemplo é ilustrativo: a preservação da vida humana, de certo, é um valor que nosso ordenamento jurídico leva em conta como algo que Canaris, de certo, julgaria como um valor fundamental. Logo, deveria vir sempre estruturado sob a forma de um princípio. Contudo, parece-nos também ser lugar comum a idéia de que o artigo 121 do Código Penal se estruture como uma regra. Daí a pergunta: ora, esse mandamento (regra) não traria subjacente a si um valor fundamental de todo o ordenamento jurídico?

Contudo, essa concepção que vê princípios como valores que informariam todo o Direito encontra ressonância na língua portuguesa. Celso Antônio Bandeira de Mello sustenta que os princípios são os mandamentos nucleares, o alicerce do sistema jurídico, eis que seriam a base e diretriz para a correta compreensão dos mesmos. Somente pelo auxílio dos princípios seria possível ao intérprete alcançar uma visão unitária do ordenamento jurídico. Desse modo, a violação de um princípio seria muito mais grave do que a transgressão de uma regra, eis que implicaria uma ofensa não a um mandamento específico, mas ao sistema como um todo 9 .

Canotilho enxerga a Constituição formada por intermédio de normas de distintos graus de densidade semântica, de modo a diferenciar regras de princípios e, indo além, para classificar os princípios dentro de uma hierarquia normativa em princípios estruturantes, princípios constitucionais

${ }^{9}$ Cf. MELlO, Celso Antônio Bandeira de. Elementos de Direito Administrativo. São Paulo: Revista dos tribunais, 1980, p. 230. 
gerais, princípios constitucionais especiais ao lado das demais normas (regras) constitucionais. ${ }^{10}$ Desse modo, não só percebe haver uma hierarquia entre regras e princípios como também uma valoração possível entre as normas constitucionais principiológicas.

A tese de Canotilho esbarra, na atualidade, na moderna concepção de unidade que permeia a Constituição, desde a contribuição de Otto Bachof ${ }^{11}$ e, posteriormente, com o trabalho de Müller sobre o postulado denominado de "concordância prática" entre possíveis antinomias constitucionais. Contudo, é curioso anotar que o próprio Bachof se posicionava também por meio da proeminência do princípio da isonomia, de modo que, conjuntamente com a noção da dignidade da pessoa humana, pudesse ser a matriz substantiva do texto constitucional, sem se dar conta de que tal posição afetaria sua maior contribuição para o constitucionalismo mundial.

Nessa esteira, Geraldo Ataliba ${ }^{12}$, dando seqüência a uma longa tradição no direito brasileiro, sustenta a visão de que as regras jurídicas teriam sua aplicação condicionada pelos princípios, de modo a reconhecer uma hierarquia entre essas espécies normativas.

Mas por que os princípios teriam tal posição? Na opinião de Miguel Reale, os princípios se aproximariam da noção de valor, tornando-se "verdades fundantes de um sistema de conhecimento, como tais admitidas "por serem evidentes ou por

\footnotetext{
${ }^{10}$ Cf. CANOTILHO, José Joaquim Gomes. Direito Constitucional. 4. ed.

${ }^{11}$ Cf. BACHOF, Otto. Normas constitucionais inconstitucionais. Tradução de José Manuel M. Cardoso da Costa.Coimbra: Almedina, 1994.

12 ATALIBA, Geraldo. República e Constituição. São Paulo: Revista dos tribunais, 1985.
}

terem sido comprovadas', mas também pela necessidade da práxis"13. A postura de Reale se aproxima da posição de Karl Larenz que, por sua vez, concebe os princípios como uma etapa entre as normas jurídicas e os valores. Desse modo, os valores seriam concepções de justiça dominantes na sociedade - ethos jurídico dominante - e que guiam a atividade hermenêutica ${ }^{14}$.

São vários os problemas de tais concepções. Canotilho, Ataliba, Bachof acabam por não distinguir as normas jurídicas dos valores a elas subjacentes. Está claro que qualquer ordenamento jurídico traz consigo a expressão de valores que tem a pretensão de contribuir para a estabilização das expectativas racionais de comportamento. Contudo, tal como visto, o Direito opera sob um código binário que o faz distinto da noção de gradualidade inerente aos valores.

Ademais, quando Larenz expõe seu ponto de vista, com suporte em Zippelius, deixa claro transparecer sua visão comunitarista da sociedade: ele entende haver um "ethos

${ }^{13}$ REALE, Miguel. Lições Preliminares de Direito. São Paulo: Saraiva, 1988, p.299.

${ }^{14} \mathrm{Na}$ verdade, o princípio maioritário não é, enquanto tal, critério de justeza, mas, no entanto, ZIPPELIUS refere com o "ethos jurídico" apenas as idéias que podem compreender-se como a concretização da idéia de Direito, dos princípios básicos de uma ética da vida social, facto que não deixará de importar para que aspirem a um reconhecimento. Uma vez que o juiz. aplica o Direito em nome dessa comunidade jurídica, só pode ter em conta a Ética nela vigente, que pervive (em maior ou menor grau) nos membros dessa comunidade, conformando-lhes o comportamento e o critério de julgamento. Nesta medida, damos razão a ZIPPELIUS. O conceito de "ethos jurídico" encerra um elemento empírico e um elemento normativo, não indicia apenas os resultados de um inquérito de opinião. (LARENZ, Karl. Metodologia da Ciência do Direito. Tradução de José Lamego. 3. ed. Lisboa: Fundação Calouste Gulbekian, 1997, p.174). 
jurídico" dominante capaz de fornecer quais seriam os valores dominantes para fins da aplicação do Direito. Contudo, em sociedades profanizadas como as atuais fica difícil estabelecer de modo a priori quais os conteúdos desse ethos, eis que os projetos pessoais e as concepções do que seja "vida boa" são os mais distintos em termos de religião, moral, ética, economia, opção sexual, etc. Nesse sentido, quando Habermas toma a concepção de direitos humanos universais, essencialmente liberdade e igualdade, o faz como condições para o discurso que se abrirá. Logo, não cai em um possível retorno a polis grega.

Por fim, as percepções de generalidade incorrem em um erro sério. Primeiro, porque não são todos os princípios que podem ser generalizados a partir de regras. De outro lado, alguns seriam tão amplos que acabariam sendo generalização de todo o ordenamento jurídico, tal como o princípio do Estado de Direito e o princípio do Estado Democrático, se observada a própria classificação de Canotilho.

Por exemplo: o princípio federativo, adotado pela Constituição Brasileira, seria uma generalização de quê? O princípio da legalidade generaliza quais normas? (...) Esse não pode ser, portanto, o critério adotado. Não se nega com isso que, na maioria das vezes, os princípios possuam maior grau de generalização. O que se quer dizer é que a generalidade não é uma causa, mas, quando muito, uma conseqüência do conceito de princípio, e não diferencia essencialmente, mas só geralmente as duas categorias. ${ }^{15}$

Boulanger procura responder a objeção colocada por Galuppo em outras bases. Para

${ }^{15}$ GALUPPO, Igualdade e Diferença, p. 171, sem destaque no original. ele, está claro que a generalidade não é um traço que per se possa distinguir regras de princípios, eis que presente em ambas as espécies normativas. Contudo, sustenta que a forma de incidência da generalidade é diferente quando se está diante de regras e de princípios. No primeiro caso, a generalidade se manifesta de forma especial, visto que a regra incidiria em uma situação jurídica determinada, a despeito da pluralidade de atos ou fatos por ela regulados. Já no tocante aos princípios, não há uma situação determinada de modo a priori para sua incidência.

Destaque-se que a posição de Boulanger ${ }^{16}$ não é isolada na doutrina. Eros Grau anota também o apoio de Crisafulli ${ }^{17}$ a esse critério estrutural relativo à generalidade das espécies normativas. Em sua visão,

(...) os primeiros se caracterizam pela sua maior generalidade, em relação às últimas; o preceito contido no princípio geral compreende não uma só hipótese determinada, mas uma série indeterminada de hipóteses, qualquer das quais suscetíveis de ensejar inúmeros - e diversos - facti species; por outro lado, desde o critério funcional, os princípios são normas - escritas e não escritas - das quais logicamente derivam as normas particulares - também estas escritas ou não escritas - e às quais, inversamente, se chega a partir destas últimas (p. 239). Assim, o critério - estrutural - da generalidade não é senão consequiência necessária da consideração do critério funcional: os princípios gerais, porque dotados de generalidade mais ampla, compreendem

${ }^{16}$ Cf. BOULANGER, Jean. Principes géneraux $d u$ droit positif et droit positif. In Le Droit Privé Français au milieu du XX $X^{e}$ siècle (Études offertes a Georges Ripert). Paris: LGDJ, 1950.

${ }^{17}$ CRISAFULLI, Vechio. Per la determinazione Del conetto dei principi generali Del Diritto. In: Revista Internazionale de Filosofia Del Diritto, v. XIX.Ano XXI, série II, jan. abr. de 1941. 
uma série indeterminada de facti species (dados ou possíveis) distintos (p. 240). ${ }^{18}$

De modo simplista, as teorias de Boulanger e de Crisafulli podem ser metaforizadas por meio de jogos de salão, tal como o "buraco" e o xadrez. Desse modo, enquanto as regras podem ser vistas como qualquer carta de baralho que tem um lugar certo para ser encaixada, os princípios podem ser vistos como o coringa que pode entrar em qualquer posição. Da mesma forma, no jogo do xadrez, todas as peças têm uma forma espécie de movimentação, enquanto apenas a Rainha pode valer-se de mais de uma maneira para se mover. Assim, os princípios se aproximariam do modelo da Rainha, enquanto as regras ficariam com a figura das outras peças.

Adespeito de ser uma tese de palatabilidade fácil, refutar sua sustentação não é difícil porque, mesmo se voltássemos a uma gramática hermenêutica tradicional, a tese da indeterminação da tipicidade não se sustentaria. Primeiro pelo fato de que essa tese não explicaria a questão da analogia. Desse modo, uma regra é utilizada para uma situação absolutamente diversa daquela para o qual teria sido concebida originariamente pelo legislador. Poderia, então, seus adeptos dizer; ora, mas o emprego da analogia é excepcional e na atualidade em razão da "inflação legislativa” os casos de analogia serão cada vez menores. No entanto, essa réplica não convence simplesmente porque procura contornar o problema, algo que não ocorre como os óbices seguintes. E o segundo pode vir ainda dentro dos limites da filosofia

${ }^{18}$ GRAU, Eros. A ordem econômica na constituição de 1988 (interpretação e crítica). 2. ed. São Paulo: Revista dos tribunais, 1991, p. 113. da consciência. O próprio positivismo legalista já percebera, por meio da técnica da voluntas legis, que uma regra pode ser aplicada para um sem-número de casos não concebidos originariamente pelo legislador. Logo, aqui não se trata de uma exceção, mas de algo que ocorre permanentemente.

Contudo, o problema principal dessa forma de se distinguir as espécies normativas não foi alcançado simplesmente porque não superou os limites do positivismo jurídico e da relação sujeito/objeto na ciência jurídica. A questão está justamente no fato de que tais suposições mantêm ainda como possível a dicotomia entre fato e norma, seja então regra ou princípio. A questão da indeterminação da facti specie ou da abstração tipológica da norma parte de uma análise sintático/ semântico dos textos legais, algo já de há muito superado pelo giro lingüístico. Assim, analisar textos legais fora de seu contexto de aplicação pode, no máximo, gerar preconceitos de fundo metafísico no intérprete, eis que não há norma desconectada de sua faticidade.

Assim, acreditamos superada também a suposição de que a baixa densidade pudesse ser assestada tão-somente contra certas expressões caracteristicamente polissêmicas, vagas, porosas. Alguém poderia insistir: tudo bem, a classificação reconhece tal limitação e preferimos aderir a ela, mesmo sabendo que estaremos retornando ao positivismo. Nesses termos, a taxionomia seria científica? A resposta é negativa. Primeiro, porque tal retorno já não se faz possível, simplesmente porque o nível de racionalidade a que chegamos não admite esse passo para trás. Segundo, porque tal classificação não teria encontrado um critério lógico para diferenciar 
as espécies normativas, eis que todo texto é aberto a inúmeras interpretações. Em outras palavras, também as "regras" teriam uma tipicidade/conceitualidade aberta. O problema de tal classificação está exatamente no fato de se dizer que alguns textos (regras) admitem uma univocidade de sentidos e que outros (princípios) não. Contudo, desde Heidegger sabemos que essa premissa, mais do que metafísica, é irracional e não científica.

Não olvidamos que, a despeito de termos por claro que toda comunicação humana pressupõe contrafaticamente um médium lingüístico, assiste razão à hermenêutica contemporânea no sentido de que não é possível apriorísticamente sustentar que um termo seja poroso/aberto e outro não, ou mensurar essa vagueza de modo a permitir um retorno subreptício às concepções de aplicação silogística para os dispositivos que forem tidos por mais precisos. Günther, atento à questão, posiciona-se sobre o tema:

Contra a tese da hermenêutica alegou-se que uma indeterminação da norma somente ocorreria em casos de termos polissêmicos, vagos, porosos e que ainda precisam ser preenchidos com valores, bem como em casos de aplicação de termos disposicionais. Neste caso, um significado deveria ser fixado e fundamentado por meio de cânones de interpretação, juízos antecipados e preceitos da dogmática. Como demonstraram as reflexões acima a respeito da lógica de argumentações da adequação, exigem-se regras de uso lexical para garantir a justificação externa de uma decisão jurídica. No entanto, a sua justificação externa não consegue justificar a seleção vinculada a uma determinação de significado de sinais característicos situacionais, a partir de uma descrição situacional integral. ${ }^{19}$

No entanto, os esforços do paradigma moderno de estabelecer uma distinção entre

\footnotetext{
${ }^{19}$ GÜNTHER, Teoria da argumentação, p. 399.
}

as regras e os princípios não se esgotaram nas teorias acima descritas. Desse modo, cabe aqui ainda anotar duas outras tentativas: a primeira ligada à noção da positividade e a segunda em torno de uma análise morfológica empreendida por Joseph Esser.

O critério da positividade para as regras e da transcendência para os princípios é bem simples: os princípios poderiam ser ou não positivados e as regras precisariam necessariamente ser positivados. Assim, mesmo que revogadas, as regras teriam tido vigência algum tempo atrás como normas jurídicas e os princípios poderiam ser incorporados no direito sem um texto legislativo específico, tal como se processa atualmente com os chamados princípios abertos e anteriormente com os princípios gerais de Direito.

A objeção também não é relevante. Primeiro, porque o Direito não é criação exclusiva do Estado, tal como se percebe claramente com os costumes. Segundo, porque os princípios não são criados pelo julgador ou pela doutrina, e sim reconstruídos a partir do Direito em sua totalidade, envolvendo aqui algo que vai seguramente muito além de textos positivados. Acrescentese a isso que, em geral, aqueles que sustentam esta tese ligam-na também à questão da generalidade. Contudo, ficaria o problema: ora, se os princípios são generalizações de regras, como então eles poderiam abdicar da positividade ${ }^{20}$

${ }^{20}$ O ponto central a ponderar, ao deles cuidarmos, é o referido a não transcendência dos princípios gerais do Direito. Com efeito, eles não constituem criação jurisprudencial, por outro, externamente ao ordenamento - ou à Constituição. Assim, a autoridade judicial, ao tomá-los dmodo decisivo para a definição de 
Os últimos esforços do presente paradigma se devem aos trabalhos de Josef Esser e Robert Summers. Vejamos, pois, cada um deles.

Esser $^{21}$, por sua vez, vê a distinção sob um enfoque original: ele sustenta que os princípios não configurariam mandamentos e sim diretrizes, critérios e justificação para a aplicação do Direito. Em outras palavras, o critério de distinção das espécies normativas seria o fundamento que cada uma, regra e princípio, exigiria para a tomada de uma decisão.

Nesse sentido, Esser entendia que os princípios forneceriam motivos para que o intérprete pudesse empregar esse ou aquele mandamento, enquanto as regras exigiam uma argumentação que se ligaria diretamente à própria decisão. Logo, os princípios não seriam em si mesmos mandamentos, mas apenas instruções para o emprego das regras. Os princípios constituiriam parte do Direito positivo, não como mandamentos autônomos, mas como uma (pré)condição para o funcionamento das regras. Desse modo, o princípio da função social da propriedade pode ser concebido como integrante do Direito positivo, eis que inerente à compreensão do próprio instituto do direito de propriedade, conferindo-lhe causa e justificação para seu emprego.

O modelo de Esser parte do pressuposto de um modelo de Direito problemático, ou seja, ligado à pratica judicial (jurisprudência) e pela prudência aristoteliana (phrónesis), muito provavelmente por influência da tópica

terminada solução normativa, simplesmente comprova a sua existência no bojo do ordenamento jurídico, do Direito que aplica, declarando-os. (Grau, A ordem econômica na Constituição de 1988, p. 129).

${ }^{21}$ ESSER, Josef. Princípio y norma en la elaboración jurisprudencial Del Derecho Privado. Tradução de Eduardo Valenti Fiol. Barcelona: Bosch, 1961. de Viehweg ${ }^{22}$. Seu ponto de partida era, pois, uma contraposição ao sistema fechado de Direito em torno de uma concepção piramidal do ordenamento jurídico ${ }^{23}$. Assim, o papel do magistrado na revelação de princípios confere uma abertura ao Direito que ia bem além dos limites positivistas da sua época.

Galuppo anota com razão que a contribuição de Esser antecipa conceitos centrais do paradigma contemporâneo da teoria dos princípios por duas razões. Primeiro, por reconhecer a dualidade dos planos de aplicação e de justificação das normas jurídicas. Depois, porque admite que a argumentação discursiva é essencial à

${ }^{22}$ Segundo Esser, o ato de aplicar a lei está inserido em um juízo antecipado valorativo, que integra cada norma em um sistema teleológico aberto, orientado por princípios. À semelhança de Kriele, também Esser, ao fazer essa observação, orienta-se pelo exemplo de um modo de pensar em termos do Direito de caso, que considera cada situação nova à luz da ratio decidendi de casos previamente decididos e de sua correlação por meio de princípios. O princípio (...) domina a interpretação de norma de rule [regra], ou seja, domina a direção da seleção prévia e do reconhecimento de fatos que podem ser juridicamente levantados na realidade objetiva, e do reconhecimento de observações que podem ser juridicamente levantados na realidade objetiva, $e$ do reconhecimento de observações que podem ser juridicamente levantadas no precedent (precedente). (Günther, Teoria da argumentação, p. 401).

${ }^{23}$ No caso do modelo axiomático, ou seja, aquele cujo centro de gravidade é a construção de um sistema hierarquizado, o ponto de partida por excelência é o Código. Segundo Esser, o pensamento axiomático desvaloriza elou ignora "os princípios valorativos abertos, as doutrinas, máximas, parêmias, etc. (...). Em lugar deles põe em primeiro plano as rationes legis, os princípios formais e a estrutura da lógica jurídica”. (Galuppo, Marcelo. A contribuição de Esser para a reconstrução do conceito de princípios jurídicos. Belo Horizonte: Editora da Faculdade de Direito da UFMG: Revista de Direito Comparado, n. ${ }^{\circ}$ 03, maio/1999, p. 227/244, p. 234). 
conformação do Direito ${ }^{24}$. Acrescentaríamos um terceiro aspecto: a busca pela distinção das espécies normativas passa a ser seguida na aplicação do Direito ${ }^{25}$.

Nesse sentido, o trabalho de Esser, datado da década de 1950, parece esforçar-se para dar um passo além das concepções kelsenianas para a conformação do Direito, ao entender que o ordenamento jurídico conteria mais do que regras. Contudo, o passo é ainda tímido, se visto com olhos atuais. Isso porque sua teoria só concebe os mandamentos jurídicos sob uma estrutura morfológica hipotética condicional, ou seja, que somente as regras poderiam ser mandamentos/normas jurídicas ${ }^{26}$ e, como tais, apenas elas poderiam se encaixar no modelo (ainda kelseniano) do "se é A, deve ser B". Em outras palavras, as regras se estruturariam sob a dualidade hipótese/ conseqüência enquanto os princípios seriam tão-somente fundamento para as decisões para a aplicação dessa ou daquela regra.

Todavia, seu esforço é em vão, como bem demonstra Humberto Ávila:

(...) a existência de uma hipótese de incidência é questão de formulação linguiística e, por isso, não pode ser elemento distintivo de uma espécie normativa. De fato, algumas normas que são

${ }^{24}$ Cf. GALUPPO, A contribuição de Esser para a reconstrução do conceito de princípios jurídicos, p. 240.

${ }_{25}$ Apenas como alerta ao leitor, deve ficar claro que tais antecipações não aproximam Esser das teorias contemporâneas.

${ }^{26}$ Um princípio jurídico não é um preceito jurídico, nem uma norma jurídica em sentido técnico, eis que não contém nenhuma instrução vinculante de tipo imediato para um determinado campo de questões, mas requer ou pressupõe a cunhagem judicial ou legislativa de tais instruções. (ESSER, Josef. Princípio y norma en la elaboración jurisprudencial Del derecho privado. Barcelona; Bosch, 1961, p. 65, tradução livre e sem destaque no original). qualificáveis, segundo esse critério, como princípios podem ser reformuladas de modo hipotético, como demonstram os seguintes exemplos: "Se o poder estatal for exercido, então deve ser garantida a participação democrática" (princípio democrático); "Se for desobedecida a exigência de determinação da hipótese de incidência de normas que instituem obrigações, então o ato estatal será considerado inválido" (princípio da tipicidade). ${ }^{27}$

Os exemplos de Ávila não param por aí. Nesse sentido, o princípio da legalidade tributária pode ser expresso tanto nos moldes do artigo 150, inciso I, da nossa Carta vigente $^{28}$, quanto da seguinte maneira: "se houver instituição ou aumento de tributo, então a instituição ou aumento deve ser veiculado por lei”. Da mesma maneira o dito princípio da anterioridade tributária ${ }^{29}$ : "se houver instituição ou aumento de tributos, então só podem ser abrangidos fatos geradores ocorridos após o início da vigência da lei que os houver instituído ou aumentado"30.

Esser não percebe que a morfologia de uma norma jurídica não predetermina sua interpretação. Ele não percebe ainda que a dialética hermenêutica promove uma fusão de horizontes entre o texto interpretado e o intérprete de modo que nem um nem o outro

\footnotetext{
${ }^{27}$ ÁVILA, Teoria dos princípios, p. 32.

${ }^{28}$ Sem prejuízo de outras garantias asseguradas ao contribuinte, é vedada à União, aos Estados, ao Distrito Federal e aos Municípios:

I - exigir ou aumentar tributo sem lei que o estabeleça;

${ }^{29}$ Sem prejuízo de outras garantias asseguradas ao contribuinte, é vedada à União, aos Estados, ao Distrito Federal e aos Municípios:
}

III - cobrar tributos:

a) em relação a fatos geradores ocorridos antes do início da vigência da lei que os houver instituído ou aumentado;

${ }^{30}$ Cf. ÁVILA, Teoria dos princípios, p. 33/34. 
possam de modo a priori fixar sentidos prévios. Dito de outro modo, a forma de exteriorização de um texto não tem o condão de fixar a maneira pelo qual será compreendido pelo seu intérprete. Desse modo, Esser se mostra ainda ligado a uma concepção de interpretação anterior ao giro lingüísticopragmático, eis que ela ainda se mantém ligada a padrões da relação sujeito-objeto.

Essa última tese de Esser pode ser associada à tese de Summers ${ }^{31}$, que sustenta que os princípios produziriam razões substantivas ou finalísticas enquanto as regras trariam consigo apenas razões de correção ou autoritativas. A despeito de também orientar sua contribuição em torno da aplicação do Direito, a obra de Summers traz mais uma vez associação direta à noção de princípios como valores que consistiriam em um pano de fundo para a aplicação do Direito, que, no fundo, ficaria restrito às regras. Ávila resume de forma interessante esse ponto de vista:

Por exemplo, a interpretação do princípio da moralidade irá indicar que a seriedade, a motivação e a lealdade compõem o estado de coisas, e que comportamentos sérios, esclarecedores e leais são necessários. O princípio, porém, não indicará quais são, precisamente, esses comportamentos. Já no caso das regras (...) o aplicador também pode considerar elementos específicos de cada situação, embora sua utilização dependa de um ônus de argumentação capaz de superar as razões para cumprimento da regra. A ponderação é, por consequiência, necessária. Isso significa que o traço distintivo não é o

${ }^{31}$ SUMMERS, Robert. Two types of substantive reasons: the core of a theory of common law justification. In: The Jurisprudence of Law's Form and Substance (Collected Essays in Law). Alderhot, Ashgate, 2000, p. $155-236$. tipo de obrigação instituído pela estrutura condicional da norma, se absoluta ou relativa, que irá enquadrá-la numa ou noutra categoria de espécie normativa. É o modo como o intérprete justifica a aplicação dos significados preliminares dos dispositivos, se frontalmente finalístico ou comportamental, que permite o enquadramento numa ou noutra espécie normativa. ${ }^{32}$

Seria por demais simplista rejeitar a tese de Summers tão-somente por ele sustentar que apenas na aplicação das regras seria necessária a consideração dos elementos específicos da situação concreta. Não que esse seja um problema pequeno. Mas acreditamos haver outro óbice tão sério quanto o primeiro, mas que não é óbvio para o leitor comum. Summers procura a distinção das espécies normativas na argumentação específica para o emprego de princípios e regras. Mas, qual seria esse problema?

Para compreendê-lo melhor é importante deixar claro que seu trabalho se esforça muito para implementar a superação do positivismo legalista - entendido aqui no sentido de haver um imperativo à obediência cega aos textos legais. Logo, a noção de rightness reasons (fundamentos de correção) poderia justificar no caso concreto porque o intérprete teria deixado de aplicar uma regra que aparentemente lhe fosse "adequada". Ou seja, as regras exigiriam uma argumentação específica para serem ou deixarem de serem aplicadas no intuito de obtenção de uma decisão correta para cada caso.

Contudo, Summers não percebe que, não apenas as regras, mas todo Direito exige do intérprete o emprego de 'razões de correção'

32 ÁVILA, Teoria dos Princípios, p. 40/41, sem destaque no original). 
com o fito de alcançar a "resposta correta" na sua aplicação. Não é, pois, possível dizer que o operador do Direito empregue apenas as razões de correção quando for trabalhar tãosomente com parte do ordenamento jurídico, ou seja, as regras. De fato, subjacente ao esforço de Summers está o "preconceito", em sentido gadameriano, de que os princípios seriam por demais abstratos e que, por conseguinte, só poderiam colaborar mediante a consecução de fins para a aplicação do Direito.

Por conseguinte, consideramos ser inútil continuar desfiando os mesmos argumentos de outros doutrinadores ligados ao paradigma moderno, eis que as mais diferentes tentativas operadas para estabelecer a distinção entre as espécies normativas nesse paradigma acabaram esbarrando nas limitações da filosofia da consciência e nas insuficiências de uma hermenêutica alienada da história efetual e do mundo da vida. Assim, percebe-se que todo esforço empreendido no sentido de buscar sintática ou semanticamente características morfológicas típicas de regras e de princípios deu em nada. Curioso, no entanto, observar que, a despeito de tal constatação, não são poucos os que na doutrina nacional continuam divulgando tais teses, agora ligadas também às contribuições do paradigma contemporâneo, como se fossem compatíveis.

Assim, pode-se dizer que Ronald Dworkin inaugurou o paradigma contemporâneo da teoria dos princípios, buscando agora proceder à distinção por meio do modo de operação/aplicação das regras e dos princípios. Nesse sentido, Dworkin foi o primeiro a empreender tal esforço e o fez ainda na década de 1960.
Para melhor situar o contexto em que o texto The Model of Rules I foi escrito, é preciso entender que nosso autor estava empenhado na superação das diferentes formas de hermenêutica judiciária que, à época, eram inteiramente tributárias do positivismo ${ }^{33}$, do utilitarismo ou de algumas variações originais da common law norte-americana, o convencionalismo ${ }^{34}$ e o pragmatismo.

De modo sintético, Dworkin sustenta que a forma de aplicação das regras se submete ao modelo do tudo ou nada (all or nothing), no sentido de que em caso de antinomia entre regras, uma delas será considerada inválida.

${ }^{33}$ O positivismo possui como esqueleto algumas poucas proposições centrais e organizadoras. (...) (a) $O$ direito de uma comunidade é um conjunto de regras especiais utilizado direta ou indiretamente pela comunidade com o propósito de determinar qual comportamento será punido ou coagido pelo poder público. Essas regras especiais podem ser identificadas e distinguidas com auxílio de critérios específicos, de testes que não tem a ver com seu conteúdo, mas com o seu pedigree ou maneira pela qual foram adotadas ou formuladas (...) (b) O conjunto dessas regras jurídicas é coextensivo com o "Direito", de modo que se o caso de alguma pessoa não estiver claramente coberto por uma regra dessas (...) então esse caso não pode ser decidido mediante " $q$ aplicação do direito". Ele deve ser decidido por alguma autoridade pública, como um juiz, “exercendo seu discernimento pessoal”, o que significa ir além do direito na busca por algum outro tipo de padrão que o oriente na confecção de nova regra jurídica ou na complementação de uma regra já existente. (DWORKIN, Levando os direitos a sério, p. 28)

${ }^{34}$ Existem diferenças óbvias entre o convencionalismo e as teorias semântico-positivistas que discuti no primeiro capítulo. Mas há uma importante diferença. As teorias semânticas afirmam que a descrição que acabamos de apresentar se concretiza e se aplica por meio do próprio vocabulário jurídico, de modo que seria uma espécie de auto-contradição dizer que o Direito confere direitos para além daqueles estabelecidos por mecanismos sancionados por convenção. A concepção convencionalista do direito, ao contrário, é interpretativa: não faz nenhuma afirmação lingüística ou lógica dessa natureza. (DWORKIN, O Império do Direito, p. 32). 
Logo, se a hipótese de incidência da regra viesse a ser atendida, sua conseqüência deveria ser aplicável, exceto se a norma fosse tida por inválida ${ }^{35}$. A seu ver está claro que regras podem ter exceções; contudo, se a lista for longa demais, ela poderá acabar se transformando em outra regra, ou seria desajeitado demais recitar toda a lista de casos excepcionais descritos na norma. Por conseguinte, ele sustenta que se uma lei civil determina que a validade de um testamento seja a presença de três testemunhas, de certo que se o documento for assinado apenas por duas pessoas ele não será tido por válido.

Mas não é assim que funcionam os princípios apresentados como exemplos nas citações. Mesmo aqueles que mais se assemelham a regras não apresentam consequiências jurídicas que se seguem automaticamente. Quando as condições são dadas. Dizemos que o nosso direito respeita o princípio segundo o qual nenhum homem pode beneficiar-se dos erros que comete (a ninguém é dado valer-se de sua própria torpeza"). Na verdade, é comum que as pessoas obtenham vantagens, de modo perfeitamente legal, dos atos jurídicos ilícitos que praticam. O caso mais notório é o usucapião - se eu atravesso suas terras sem autorização durante muito tempo, algum dia adquirirei o direito de cruzá-las quando o desejar. Há muitos exemplos menos dramáticos. Se um homem abandona seu trabalho, rompendo um contrato, para assumir outro emprego mais bem pago, ele pode ter que pagar indenização a seu primeiro empregador,

${ }^{35}$ A diferença entre princípios jurídicos e regras jurídicas é de natureza lógica. Os dois conjuntos de padrões apontam para decisões particulares acerca da obrigação jurídica em circunstâncias específicas, mas distinguem-se quanto à natureza da orientação que oferecem. As regras são aplicáveis à maneira do tudo-ou-nada. Dados os fatos que uma regra estipula, então ou a regra é válida, e neste caso a resposta que ela fornece deve ser aceita, ou não é válida, e neste caso em nada contribui para a decisão. (DWORKIN, Levando os direitos a sério, p. 39). mas em geral ele terá direito de manter seu novo salário. Se um homem foge quando está sob fiança e cruza a fronteira estadual para fazer um investimento brilhante em outro estado, ele poderá ser remetido de volta á prisão, mas ele manterá os lucros. ${ }^{36}$

Desse modo, percebe-se que os princípios não fixam absolutamente sua aplicação, eis que exigem uma atitude reflexiva do intérprete de modo a respeitar-lhe sua dimensão de peso. Assim, não existem princípios contraditórios e sim princípios que concorrem entre si. E a solução de tal concorrência não deve seguir a proposta de discricionariedade inerente ao positivismo, mas uma reflexão que traduza os aspectos mais relevantes e profundos da moralidade política.

Ao contrário de Alexy, esse procedimento não pressupõe uma gradação, mas uma cessão de um princípio diante do outro no caso concreto, por meio de exceções de aplicação. "Um dos dois princípios deve ceder nestas circunstâncias” (Dworkin, 1886:270), e não necessariamente em outras circunstâncias. Ao contrário de Alexy, Dworkin parte do pressuposto de que o que move essa decisão é a exigência contingente de prosseguimento da jurisdição e do processo, ligadas à Integridade do Direito:

"é exigido de mim que encontre um lugar em toda interpretação geral de nossa prática legal para todos os princípios (...). Nenhuma interpretação geral que negasse qualquer uma delas seria plausível; a Integridade não poderia ser satisfeita se qualquer um deles fosse completamente rejeitado. Mas a Integridade exige que alguma solução de sua colisão competitiva (...) seja tomada (...). A Integridade exige isto porque exige que eu termine a questão. ${ }^{37}$

\footnotetext{
${ }^{36}$ DWORKIN, Levando os direitos a sério, p. 40.

${ }^{37}$ GALUPPO, Igualdade e diferença, p. 188.
} 
Galuppo já antecipa algumas diferenças entre a proposta de Dworkin e aquela procedida por Alexy. No entanto, entendemos que a teoria dos princípios do segundo foi fruto do esforço do autor de "refinar" a visão do primeiro. Assim, Alexy vai procurar construir uma distinção no âmbito da aplicação normativa, tal qual fez Dworkin. Mas, quais são suas particularidades?

Para Alexy, a distinção entre regras e princípios deve ser compreendida como um elemento essencial para a passagem da hermemêutica positivista para uma hermenêutica pós-positivista. Nesse sentido, os princípios são normas jurídicas prima facie $^{38}$, eis que plasmariam mandados de otimização aplicáveis sob distintas possibilidades fáticas. Desse modo, os princípios se distanciariam das regras por assumir uma dimensão de peso pela qual seria impossível para o intérprete fixar de antemão suas conseqüências normativas.Desse modo, o eventual choque principiológico se resolveria pela "lei de colisão", por meio da qual, partindo-se da idéia da ponderação de valores $^{39}$, busca a formulação de regras de

\footnotetext{
${ }^{38}$ Para Alexy, tanto las reglas como los princípios son normas porque ambos dicen lo que debe ser. Ambos pueden ser formulados con ayuda de las expresiones deónticas básicas del mandato, la permisíon y la prohibición. Los principios, al igual que las reglas para juicios concretos de deber ser, aun cuando sean razones de un tipo тиy diferente. La distinción entre regals y principios es pues uno distintición entre dos tipos de normas. (ALEXY, Robert. Teoria de los derechos fundamentales. Madrid: Centro de Estúdios Constitucionales, 1997, p.83).

39 Alexy percebe o problema de trabalhar axiologicamente o Direito. Contudo, a despeito de pretender escapar de tal engodo, acaba por justificar a forma de aplicação do Direito por meio de uma argumentação utilitarista de um método que possibilitaria racionalizar as escolhas entre os meios e fins das medidas impugnadas.
}

prevalência que permitiriam que os princípios viessem a ser tratados deontologicamente, ou seja, sob a lógica do tudo ou nada.

Seu raciocínio privilegia uma análise hermenêutica que levaria em conta tanto possibilidades normativas quanto fáticas, eis que as "regras de prevalência" ${ }^{40}$ somente poderiam ser justificadas com base em uma consideração das circunstâncias específicas de cada caso concreto.

De outra banda, as regras seriam normas jurídicas que expressariam mandados definitivos, eis que mero exame subsuntivo permitiria verificar o enquadramento (ou não) de suas premissas hipotéticas ao caso.

A distinção entre princípios e regras segundo Alexy - não pode ser baseada no modo tudo ou nada de aplicação proposto por Dworkin, mas deve resumir-se, sobretudo, a dois fatores: diferença quanto à colisão, na medida em que os princípios colidentes apenas têm sua realização normativa limitada reciprocamente, ao contrário das regras, cuja colisão é solucionada com a declaração de

${ }^{40} \mathrm{Ou}$ seja, a "determinação de uma relação de preferência é, de acordo com a lei da colisão, o estabelecimento de uma regra" (ALEXY, 1993b:103) que vale naquelas (e somente naquelas) condições fáticas e jurídicas. Isso significa que quando um tribunal diz que em um determinado caso (ou seja, sob dadas condições fáticas e jurídicas) um princípio precede a outro, ele diz, em essência, haver uma regra (que deve ser aplicada de modo incondicional e absoluto) que manda aplicar, naquele caso, aquele princípio, ou melhor, que determinados princípios apóiam a aplicação de regras conflitantes (ALEXY, 1993b:100). A ponderação dos princípios implica a existência de uma regra segundo a qual em toda situação em que o condicionamento fático forem exatamente os mesmos, prevalecerá sempre um único e mesmo 'princípio. Como ele afirma, "como resultado de toda ponderação jusfundamental correta, pode-se formular uma norma de direito fundamental adstrita, com caráter de regra, sob a qual pode ser subsumido o caso" (ALEXY, 1993b:98e 134). (GALUPPO, Igualdade e diferença, p. 177). 
invalidade de uma delas ou com a abertura de uma exceção que exclua a antinomia; diferença quanto à obrigação que instituem, já que as regras instituem obrigações absolutas, não superadas por normas contrapostas, enquanto os princípios instituem obrigações prima facie, na medida em que podem ser superadas ou derrogadas em função dos outros princípios colidentes. ${ }^{41}$

Em relação à diferença quanto à colisão, Alexy percebe a construção de standards discursivos específicos para cada caso concreto (regras de prevalência) ${ }^{42}$, enquanto para as hipóteses de antinomias entre regras, ele procurava refinar à perspectiva de Dworkin ${ }^{43}$ outras cláusulas de exceção além da questão da validade. Por cláusulas de exceção podemos entender tanto a possibilidade de enumeração de hipóteses excepcionais para a incidência das regras quanto às clássicas modalidades de afastamento da incidência de uma das regras. No primeiro caso, estaria o exemplo da proibição dos discentes de deixar a sala de aula durante o período de magistério e a exceção em relação a eventual aviso de incêndio. De outro lado, além do critério hierárquico (pelo qual a regra

\footnotetext{
${ }^{41}$ ÁVILA, Teoria dos princípios, p. 30).

42 (...) las condiciones, bajo las que un principio prevalece sobre outro, forman el supuesto de hecho de una regla que determina las consecuencias jurídicas del principio prevalecente. (ALEXY, Robert. Derecho y razón prática. México: Distribuiciones Fontamara, 1993, p. 17)

${ }^{43}$ Se duas regras entram em conflito, uma delas não pode ser válida. A decisão de saber qual delas é válida e qual deve ser abandonada ou reformulada, deve ser tomada recorrendo-se a considerações que estão além das próprias regras. Um sistema jurídico pode regular esses conflitos através de outras regras, que dão precedência à regra promulgada pela autoridade de grau superior, à regra promulgada mais recentemente, à regra mais específica ou outra coisa desse gênero. (DWORKIN, Levando os direitos a sério, p. 43).
}

hierarquicamente superior afasta a regra de condição inferior), que tecnicamente seria o único ligado à questão da validade, caso a entendamos por conformidade com os ditames formais e matérias de norma superior, não seria irracional acrescentar outras soluções operadas no caso de antinomia de regras, quais sejam, pelo emprego ao recurso das chamadas cláusulas de exceção, os critérios cronológico (pelo qual a lei mais recente revoga/afasta a lei anterior), da especialidade (pelo qual a regra mais específica para o caso afasta a regra de caráter mais geral) e o da territorialidade (para a solução de colisão de normas jurídicas oriundas de ordenamentos jurídicos distintos).

Quanto à obrigação, os princípios vão requerer um exame das possibilidades fáticas para sua aplicação, ligando a lei da colisão aos subprincípios da adequação e da necessidade. Já o problema das possibilidades normativas, Alexy formula sua conhecida lei da ponderação, pela qual "quanto maior seja o grau de prejuízo no tocante ao cumprimento e observância de um princípio, maior deverá ser o grau de importância para o adimplemento do outro".

Debaixo de cerradas críticas quanto à irracionalidade ${ }^{44}$ de sua lei da

${ }^{44}$ Diferentemente do que preconiza a doutrina da ponderação, não são necessárias compressões ou renúncias por parte de qualquer dos interesses conflitantes. A idéia de que algo deve ser perdido no processo de solução de um tal conflito é, concessa venia, tão incorreta como afirmar que um valor é "mais importante" ou "mais pesado" do que o outro dentro do sistema, ainda que em determinado caso. Os critérios dessa medida jamais são exteriorizados pelos teóricos da ponderação, mas antes deixados confortavelmente, sobo manto da tópica, ao subjetivismo do intérprete.

Pior ainda se afigura defender que as compressões sejam recíprocas, a fim de que um princípio não seja 
ponderação $0^{45}$, Alexy procura defender-se em textos posteriores nos quais procura explicitar critérios mais claros para o emprego da

“engolido" pelo outro. Parte-se da idéia, de duvidosa correção, segundo a qual é melhor ver dois princípios sendo aplicados numa intensidade menor que ver um aplicado em detrimento do outro. Em suma, chega-se a defender que é melhor aplicar 30\% (supondo que a aplicação de um princípio possa ser objetivamente pesada, o que é duvidoso) de dois princípios colidentes que $100 \%$ de ume $0 \%$ de outro. Com isso tamanhas podem ser as compressões que é sério o risco de alcançar-se uma solução que não tutele suficientemente qualquer dos interesses em jogo,nem proteja suficientemente qualquer das partes. (SILVA, Antônio Henrique Corrêa. Colisão de princípios e ponderação de interesses: solução ruim para problema inexistente. Rio de Janeiro: manuscrito, 2002, p, 01-23, p. 17).

${ }^{45}$ Habermas entende que a maneira pela qual Alexy concebe as leis de colisão e de ponderação implica uma concepção axiologizante do direito, pois a ponderação, nos moldes pensados pela teoria dos princípios jurídicos como mandados de otimização, só é possível porque podemos preferir um princípio a outro, o que só faz sentido se os concebermos como valores, pois é apenas porque são concebidos como valores é que os seres podem ser objeto de mensuração pela preferebilidade, constitutiva do próprio conceito de valor, uma vez que o valor, como aponta Lalande, pode ser entendido como o “caráter das coisas consistindo em que elas são mais ou menos estimadas ou desejadas por um sujeito ou, mais ordinariamente, por um grupo de sujeitos determinados" (LALANDE, 1960: 1183. Grifos meus). Ao assumir tal posição Alexy confunde as normas jurídicas (e em especial os princípios) com valores, o que torna sua teoria inconsistente, pois, de um lado, Alexy afirma:

"A diferença entre princípios e valores se reduz a um ponto. $O$ que no modelo dos valores é prima facie $o$ melhor é, no modelo dos princípios, prima facie devido; $e$ o que no modelo dos valores é definitivamente melhoré, no modelo dos princípios, definitivamente devido. Assim, os princípios e os valores se diferenciam em virtude de seu caráater deontológico e axiológico respectivamente. No direito, do que se trata é do que é devido. Isto fala em favor do modelo dos princípios" (ALEXY, 1993b:147).

Mas, de outro, ao tentar resolver o problema dos conflitos entre os princípios, o autor adota um procedimento típico da axiologia. (GALUPPO, Igualdade e diferença, p. 179/180). lei da ponderação ${ }^{46}$. Contudo, ao invés de melhorar, sua posição acaba por destruir definitivamente sua construção original, eis que passa a admitir "regras de prevalência" em abstrato, como bem observa Meyer:

Para possibilitar uma metodologia ainda mais detalhada, Alexy apresenta uma escala de interferência num princípio jurídico e não interferência em outro: esta pode ser "leve" (light), "moderada" (moderate), "séria" (serious). Essas interferências são concretas, como ele reconhece; mas pode haver certas medidas ou pesos definidos em abstrato, segundo a relação de um princípio com outro independentemente das circunstâncias de um caso concreto. $\mathrm{O}$ direito à vida, por exemplo, teria um peso em abstrato maior do que o direito de liberdade de ação. ${ }^{47}$

Alexy parece não perceber que, ao admitir possibilidades de que a lei da ponderação possa estabelecer-se de forma desconectada da realidade, sua teoria acaba definitivamente retornando ao paradigma positivista. Primeiro porque pretende cindir a interpretação em duas, eis que seu pós-positivismo se limita à aplicação dos princípios enquanto o emprego de regras ainda ficaria sob a égide do positivismo ${ }^{48}$ e de seus métodos de

${ }^{46} \mathrm{Cf}$. ALEXY, Balancing and subsumption, p. 440.

${ }^{47}$ MEYER, As sentenças intermediárias no marco de uma compreensão constitucionalmente adequada do controle jurisdicional de constitucionalidade ao paradigma procedimentalista do Estado Democrático de Direito, p. 362.

${ }^{48}$ Alexy divide as normas jurídicas em duas categorias, as regras e os princípios. Essa divisão não se baseia em critérios como generalidade e especialidade da norma, mas em sua estrutura e forma de aplicação. Regras expressam deveres definitivos e são aplicadas por meio de subsunção. Princípios expressam deveres prima facie, cujo conteúdo definitivo somente é fixado após sopesamento com princípios colidentes. (AFONSO DA SILVA. O proporcional e o razoável, p. 25). 
interpretação ${ }^{49}$. Segundo, porque, ao dizer que as "regras de prevalência da ponderação" podem ser fixadas abstratamente em caráter definitivo, abandona qualquer perspectiva lingüístico-pragmática legada pela hermenêutica como analítica existencial, desde Heidegger e Gadamer ${ }^{50}$. Logo,

${ }^{49}$ Portanto, ao se falar em "nova interpretação constitucional”, "normatividade dos princípios", "ponderação de valores", "teoria da argumentação", não se está renegando o conhecimento convencional, a importância das regras ou a valia das soluções subsuntivas. Embora a história das ciências se faça, por vezes, em movimentos revolucionários de ruptura, não é disso que se trata, aqui. A nova interpretação constitucional é fruto de evolução seletiva, que conserva muitos dos conceitos tradicionais, aos quais, todavia, agrega idéias que anunciam novos tempos e acodem a novas demandas.(BARCELLOS, Ana Paula de; BARROSO, Luís Roberto. O começo da história: a nova interpretação constitucional e o papel dos princípios no Direito Brasileiro. AFONSO DA SILVA, Luís Virgílio (Org.). Interpretação constittucional. São Paulo: Malheiros, 2005, p. 275).

${ }^{50}$ É curioso observar que a doutrina nacional tributária do pensamento de Alexy parece ter se antecipado na possibilidade de uma ponderação em abstrato, como se percebe da passagem seguinte: Quando se fala em ponderação, a imagem que em geral se formará na mente do leitor é a do magistrado colocado diante de um complexo caso concreto para o qual não há solução pronta no ordenamento ou, pior que isso, para o qual o ordenamento sinaliza com soluções contraditórias diante das quais caberá a ele decidir o que fazer: ninguém pode ajudá-lo e não há a quem recorrer. $O$ quadro que se acaba de descrever corresponde, sem dúvida, a um momento da técnica da ponderação, mas apenas a um, ou a uma das formas possíveis da sua manifestação. Tanto assim que é possível imaginar uma outra cena. Um grupo de professores se encontra para debater o conflito potencial que existe entre, e.g., a liberdade de imprensa e de informação e a intimidade, honra e vida privada. No encontro, diversos questionamentos são formulados na tentativa de demarcar as fronteiras de convivência desses bens protegidos constitucionalmente: (...) Ora, o que os professores reunidos estão fazendo é também uma forma de ponderação, só que se trata de uma ponderação em abstrato. (BARCELLOS, Ana Paula de. Alguns parâmetros normativos para a ponderação constitucional. BARROSO, Luís Roberto (Org.). A nova interpretação constitucional. Ponderação, Direitos fundamentais e relações privadas. Rio de Janeiro: Renovar, 2003, p. 60, sem destaque no original). perdem-se até mesmo as condições de possibilidade para o conhecimento, que dirá então das condições de validade do mesmo.

Alexy e seus seguidores não percebem o problema e diante das críticas propugnam cada vez mais uma racionalidade em torno de fórmulas matemáticas do peso na lei da ponderação, como se com isso fosse possível tornar racionalizável sua teoria. Tal como as avestruzes que escondem suas cabeças na terra para não ver o perigo, Alexy não percebe que sua dicotomia de espécies normativas não tem como subsistir no estágio atual de racionalidade filosófica e científica.

Ademais, seus seguidores parecem não perceber que a posição de Dworkin jamais esteve ao lado das idealizações discursivas de Alexy. Com supedâneo em Aleinikoff, podemos dizer que Dworkin jamais abandonou uma concepção deontológica do Direito, eis que no instante em que fala de dimensão de peso para a aplicação dos princípios não se submete à lógica do preferível, pois se não os chamados por ele "argumentos de princípio" não seriam trunfos necessários na operacionalização do Direito. Para Dworkin, ponderar significa refletir, avaliar, pensar, ou seja, procurar ser honesto para consigo, para com sua história de vida e de uma "comunidade de princípios" diante de um caso, enquanto para esses seguidores, ponderar implica a adoção de uma teoria particular de interpretação axiológica do Direito baseada na justificação e na racionalidade do tipo matemática. ${ }^{51}$

${ }^{51}$ In sum, balancing is not inevitable. To balance the interests is not simply to be candid about how our minds - and legal analysis - must work. It is to adopt a particular theory is interpretation that reuires justification. (ALEINIKOFF, Alexander. Constitutional law in the age of balancing. The Yale Law Journal, vol. 96, nº5, abr. 1987, p. 1001). 
Um dos erros centrais da técnica de ponderação de valores é o de não perceber que a dúvida inicial diante de um caso concreto que conduz à percepção de que haja dois princípios em colisão não passa de um uma antecipação, ou seja, de um preconceito do operador do Direito. Contudo, nem sempre isso ocorre. Nesse processo é comum tanto a "solução" nos incorrer de forma imediata quanto o operador do Direito constatar que não lhe ocorre nenhuma "feliz idéia" sobre o problema. Mas, como mera antecipação, desde Gadamer aprendemos que devemos lidar com ela de modo a evitar que essas "felizes idéias" possam conduzir o processo hermenêutico pelo caminho do decisionismo.

Depois, é preciso ficar claro que nenhum caso concreto pode ser limitado à comparação de dois princípios. Dito desse modo, quando lembramos do caso do habeas corpus n. 71373-4, apreciado pelo Supremo da década de 1990, aparentemente tínhamos dois princípios em colisão: o princípio da intimidade do filho ansioso por confirmar a paternidade daquele que ele julgava ser seu pai e, de outro lado, o princípio da integridade física e moral. Contudo, a questão de certo envolvia outros princípios? Desse modo, os princípios da liberdade de locomoção e da dignidade da pessoa humana, de certo estavam envolvidos. Assim, diriam os adeptos da ponderação, o trabalho deveria ser armar a "equação", colocando em cada lado da balança todos os princípios em questão. A resposta dada pelo Supremo baseou-se na noção do devido processo legal, de forma a impedir que alguém fosse obrigado a fazer prova contra si mesmo. Ora, o problema é que a técnica da ponderação não percebe que a decisão jamais partirá da controvérsia entre dois princípios, pois a argumentação envolve sempre todo o Direito. A resposta é encontrada pelo senso de adequabilidade dos envolvidos na questão - e aqui se trata de um processo e jamais de uma decisão solipsista do juiz - de modo a examinar todo o ordenamento do Direito em face das circunstâncias relevantes do caso concreto.

Contudo, deixemos de lado um pouco a perspectiva de Dworkin para nos aprofundarmos um pouco mais na teoria dos princípios que dá suporte aos adeptos da ponderação de valores. Assim, é que, a despeito de todos os problemas acima elencados, a perspectiva de Alexy vem ganhando cada vez mais adeptos na doutrina nacional. Alguns de seus discípulos buscam garantir a pureza de suas lições contra aquilo que denominam de ecletismo, tentando realçar as incongruências do emprego da técnica da ponderação por nossos tribunais, tal como em Afonso da Silva; outros procuram demonstrar novas perspectivas para o uso da ponderação, tal como em Humberto Bergmann Ávila e Ana Paula Barcellos. Desse modo, cumpre que adentremos no debate entre "puristas" e "alternativos" defensores da ponderação de valores.

Barcellos sustenta que, além dos critérios apontados por Alexy, seria necessário acrescentar dois elementos suplementares, quais sejam, o da indeterminação de seus efeitos e o da multiplicidade de meios para atingi- $\operatorname{los}^{52}$. Para tanto aduz, por exemplo, que o princípio do pleno emprego possa ser concretizado pelas mais variadas políticas públicas.

${ }^{52}$ Cf. BARCELlOS, Ana Paula. A eficácia jurídica dos princípios constitucionais: o princípio da dignidade da pessoa humana. Rio de Janeiro: Renovar, 2002, p. 54). 
Quanto ao aspecto da generalidade, seria desnecessário tocarmos novamente no assunto. Quanto ao segundo aspecto, Afonso da Silva sustenta - e a nosso ver com razão - que qualquer direito fundamental tem uma dupla dimensão, uma positiva, que demanda uma ação, e outra negativa, que exigiria uma omissão. Assim, quando se trata do direito de propriedade, tanto é necessário que haja política pública de garantia de casa própria para os mais carentes quanto é preciso que todos respeitem e abdiquem de ações que ofendam tal direito. E, por conseguinte, a questão da multiplicidade de meios para atingi-lo seria uma característica apenas parcial dos princípios, eis que incidiria somente na sua dimensão positiva, além do que inafastável também das regras que dariam suporte ao próprio princípio.

Se examinarmos as normas de direitos fundamentais, veremos que quase todas elas impõem tanto uma omissão quanto uma ação. A liberdade de imprensa, por exemplo, impõe tanto omissões - a não-existência de censura, por exemplo - quanto ações - a garantia de uma imprensa plural, com o combate a monopólio, poderia ser uma delas. $\mathrm{O}$ mesmo vale para o direito à vida, já que o Estado deve abster-se de matar - vedação da pena de morte, por exemplo - e, ao mesmo tempo, garantir que a vida dos cidadãos não seja ameaçada, criando e mantendo, para isso, aparatos policial e judicial eficientes, ou na elaborando leis penais eficazes, dentre outras providências. A "multiplicidade de meios para atingir efeitos pretendidos", citada por Ana Paula de Barcellos, é, portanto, uma característica apenas parcial dos princípios, ou seja, ela é somente aplicável ao âmbito positivo deles, não estando presente no seu aspecto meramente negativo, conhecido como "direito de defesa". ${ }^{53}$

${ }^{53}$ AFONSO DA SILVA, Luís Virgílio. Princípios e regras: mitos e equívocos acerca de uma distinção. Belo Horizonte: Del Rey, Revista Latino Americana de Estudos constitucionais, p. 607-628, p. 624/625).
Em nosso sentir, tal característica não logra distinguir as espécies normativas nem mesmo de forma parcial. Ora, quando se trata de direito à vida, de certo, devemos incluir textos de cunho penal, tal como a que tipifica o homicídio, seja culposo ou doloso, por exemplo. Assim, todos, e pelas mais variadas formas de abstenção (diligência no trânsito, cuidado na dispensação de remédios, vigilância para com as crianças, apenas a título de exemplificação) devem garantir o direito á vida, impedindo a prática de homicídios. Todavia, para os cultores de tal distinção, tal dispositivo não seria uma regra? Ora, mais uma vez o problema de não se compreender a hermenêutica de modo crítico, dentro do refinamento lingüístico-pragmático acaba acarretando esse tipo de distinção, a nosso ver desarrazoada.

Quanto à tese de Humberto Ávila, a importância de sua colaboração para o desenvolvimento da teoria dos princípios é significativa no contexto nacional. E, quanto às críticas que lhe são dirigidas por Afonso da Silva, cremos ser, em sua maioria, descabidas. Contudo, uma delas acerta em cheio: não há como negar que de todas as hipóteses que Ávila elenca como casos de colisão de princípios apenas uma delas pode ser enquadrada a partir da perspectiva de Alexy. Veja:

Para demonstrar sua tese, Bergmann Ávila sugere que as colisões entre princípios sejam classificadas em quatro categorias distintas; (1) a realização do fim instituído por um princípio leva à realização do fim determinado pelo outro; nesse caso, não haveria que se falar em máxima medida, mas somente em realização na medida necessária; (2) a realização do fim instituído por um exclui a realização do fim determinado pelo outro; nesse caso, o problema só poderia ser solucionado com a 
rejeição de um dos princípios. Esse tipo de colisão seria, segundo ele, semelhante aos casos de conflito entre regras. Isso o leva a afirmar que "a diferença não está no fato de que as regras devem ser aplicadas no todo e os princípios na' máxima medida'. Ambas as espécies de normas devem ser aplicadas de modo que o seu conteúdo de dever ser seja realizado totalmente"; (3) a realização do fim instituído por um só leva à realização de parte do fim determinado pelo outro; (4) a realização do fim instituído por um não interfere na realização do fim buscado pelo outro. Examinemos as quatro categorias propostas por Humberto Ávila com um pouco mais de atenção. Salta aos olhos, logo de início, que apenas a segunda delas configura uma colisão de princípios. Nas outras três hipóteses, simplesmente não há colisão. ${ }^{54}$

Contudo, a contribuição de Ávila para uma melhor compreensão da teoria dos princípios a nós parece essencial. E a razão é simples: Ávila desconstrói a tese de Alexy segundo a qual as regras somente poderiam ser aplicadas sob o modelo subsuntivo do "tudo ou nada". Em sua opinião a ponderação de valores poderia ser perfeitamente aplicável para as regras e não apenas para os princípios. Assim, também as regras teriam seu modo de operar definido por uma dimensão de peso, simplesmente porque a dimensão axiológica do Direito não está circunscrita aos princípios: ela permeia todo o ordenamento jurídico ${ }^{55}$.

${ }^{54}$ AFONSO DA SILVA, Luís Virgílio. Princípios e regras: mitos e equívocos acerca de uma distinção, p. 620).

55 Também não é coerente afirmar que somente os princípios possuem uma dimensão de peso. Em primeiro lugar, há incorreção quando se enfatiza que somente os princípios possuem uma dimensão de peso. Como demonstram os exemplos antes trazidos, a aplicação das regras exige o sopesamento de razões, cuja importância será atribuída (ou coerentemente intensificada) pelo aplicador. A dimensão axiológica não é privativa dos princípios, mas elemento integrante de qualquer norma jurídica, como comprovam os métodos de aplicação que
Desse modo, a dimensão de peso não seria um atributo específico dos princípios, capaz de os tornar distintos das regras. $\mathrm{Na}$ verdade, a dimensão do peso seria uma característica da decisão estabelecida em função das circunstâncias concretas de cada caso concreto. E dá uma série de exemplos capaz de confirmar sua tese.

O primeiro deles é particularmente interessante porque aborda matéria de cunho penal, no qual prevalece a concepção de que sua tipologia seria fechada e, desse modo, mais afeta à concepções positivistas de uma técnica subsuntiva. Ávila demonstra justamente o contrário: o caso se liga à aplicação do artigo 224 do Código Penal, pelo qual a relação sexual praticada com menor de 14 (quatorze) anos deve-se ter por presumida a violência. Contudo, a despeito do teor do texto legal, o Supremo vem considerando "circunstâncias particulares não previstas pelas normas", tais como a aquiescência da vítima e sua aparência física e (ou) mental de pessoa com idade superior ao limite do tipo ${ }^{56}$.

relacionam, ampliam ou restringem o sentido das regras em função dos valores e fins que elas visam a resguardar. As interpretações, extensiva e restritiva, são exemplos disso. Em segundo lugar, há incorreção quando se enfatiza que os princípios possuem uma dimensão de peso. A dimensão de peso não é algo que já esteja incorporado a um tipo de norma. As normas não regulam sua própria aplicação. Não são, pois, os princípios que possuem uma dimensão de peso: às razões e aos fins aos quais eles fazem referência é que deve ser atribuída uma dimensão de importância. A maioria dos princípios nada diz sobre o peso das razões. É a decisão que atribui aos princípios um peso em função das circunstâncias do caso concreto. (...) Vale dizer, a dimensão de peso não é um atributo empírico dos princípios,justificador de uma diferença lógica relativamente às regras, mas resultado de juízo valorativo do aplicador. (ÁVILA, Teoria dos princípios, p. 50/51, sem destaque no original).

${ }^{56} \mathrm{Cf}$. STF, $2^{\mathrm{a}}$ turma, HC 73.662-9, relator Min. Marco Aurelio, DJU 20.09.1996. 
Outro deles se liga à construção do conceito de improbidade administrativa. Dessa vez o Supremo absolveu Prefeita Municipal que contratou um único gari, pelo período e nove meses, sem a realização prévia de concurso público, em desacato ao disposto no artigo 37, inciso II da Constituição Federal. Na ocasião, o Supremo entendeu que sua condenação feriria o princípio da razoabilidade, eis que não ficou constatado pelas provas documentais e testemunhais qualquer prejuízo aos cofres públicos locais ${ }^{57}$.

Ávila menciona ainda um terceiro caso, curioso também por entrar em uma seara na qual a maioria dos nossos operadores do Direito julga ser privativa - ou, melhor dizendo, mais afeiçoada à técnica da subsunção - de uma conceitualidade fechada. Observe:

A legislação tributária federal estabelecia que o ingresso no programa de pagamento simplificado de tributos federais implicava a proibição de importação de produtos estrangeiros. Se fosse feita importação, então a empresa seria excluída do programa de pagamento simplificado.Uma pequena fábrica de sofás, enquadrada como empresa de pequeno porte para efeito de pagar conjuntamente os tributos federais, foi excluída desse mecanismo por ter infringido a condição legal de não efetuar a importação de produtos estrangeiros. De fato, a empresa efetuou uma importação. A importação, porém, foi de quatro pés de sofás, para um só sofá, uma única vez. Recorrendo da decisão, a exclusão foi anulada por violar a razoabilidade, na medida em que uma interpretação dentro do razoável indica que a interpretação deve ser feita "em consonância com aquilo que, para o senso comum, seria aceitável perante a lei”. Nesse caso, a regra segundo a qual é proibida a importação para a permanência no regime

${ }^{57}$ Cf. STF, $2^{\mathrm{a}}$ Turma, HC 77.003-4, Relator Min. Marco Aurelio, DJU 11.09.1998. tributário especial incidiu, mas a conseqüência do seu descumprimento não foi aplicada (exclusão do regime tributário especial), porque a falta de adoção do comportamento por ela previsto não comprometia a promoção do fim que a justificava (estímulo da produção nacional por pequenas empresas). ${ }^{58}$

Afonso da Silva, percebendo o perigo potencial de implosão da teoria dos princípios alexyana, procura responder tal assertiva. Porém, em nossa opinião, não é bem-sucedido. Ávila sustenta ancorado na opinião de Hage ${ }^{59}$ que a dimensão de peso não é fixada pela estrutura da norma, mas do uso que se faz da mesma, ou seja, que o peso é fixado em razão das circunstâncias de cada caso concreto. Para contraditá-lo, Afonso da Silva afirma que diante de uma colisão de princípios o que se aplica não é o dever-ser prima facie de um princípio e sim o dever-ser constituído pela regra prevalecente oriunda da própria ponderação ${ }^{60}$. Assim o dever-ser prima facie do princípio, que lhe permite ser aplicado de modo distinto em outros casos, permanece intacto.

Ele não percebe, entretanto, que nos casos descritos por Ávila, a conseqüência prima facie estabelecida no texto normativo não

${ }_{58}$ ÁVILA, Teoria dos princípios, p. 38.

${ }^{59}$ Cf. HAGE, Jaap. C. Reasoning with rules. An essay on legal reasoning and its underlying logic. Dordrecht, Kluwer, 1997.

${ }^{60}$ Desse procedimento de ponderação ou sopesamento resulta uma regra, aplicável ao caso concreto, cujo enunciado seria: "dadas as condições, x,y e z, o direito à honra prevalece sobre a liberdade de expressão. É essa regra que deverá ser realizada "no todo". Mas ela não se confunde com o "conteúdo de dever-ser" dos princípios, já que aplicável somente no caso concreto. $O$ "conteúdo de dever-ser" dos princípios continua sendo prima facie e, por isso, realizável em medidas diversas. (AFONSO DA SILVA, Princípios e regras: mitos e equívocos acerca de uma distinção, p. 623). 
se reproduziu na decisão judicial, atestando que as regras não podem ser entendidas como mandados definitivos, tal como preconizava Alexy. Em outras palavras, tanto regras quanto princípios constituir-se-iam em mandados prima facie, de modo que a técnica da "regra prevalecente com a ponderação de valores" pudesse ser encontrada tanto a partir do emprego de regras quanto de princípios.

Em outras palavras, Ávila procura garantir a concepção da técnica de ponderação de valores desconectada da teoria dos princípios alexyana. Contudo, a seqüência de seu trabalho, que se constitui em um esforço de estabelecer novas formas de demonstrar a distinção entre as espécies normativas, acabará por implicar um retorno indireto aos problemas inerentes à teoria da argumentação de Alexy: de um lado, a cisão da ontologia hermenêutica e, de outro, a violação do código binário do Direito.

Nesse sentido, para nós, o problema não está se devemos empregar a ponderação de valores para todo o ordenamento jurídico, como preconiza Ávila, ou apenas para os princípios, como entende Alexy. A questão, tal como debatido anteriormente, é que a ponderação de valores ameaça a legitimidade do Direito por supor que a aplicação do mesmo se dê nos mesmos patamares e limites da aplicação da moral convencional, de forma a fundir os discursos de justificação e aplicação em um mesmo amálgama ${ }^{61}$.

Quanto à questão da cisão hermenêutica, o problema se manifesta no pensamento de Ávila em outro nível. Para tanto, será necessária uma breve reconstrução da

${ }^{61}$ Cf. CRUZ, Jurisdição Constitucional Democrática. distinção de regras e princípios que ele pretende estabelecer. Com esse escopo, Ávila nos propõe alguns critérios; (a) o da dissociação justificante; (b) o da dissociação abstrata e heurística ${ }^{62}$; (c) o da dissociação em alternativas inclusivas; (d) o da natureza do comportamento prescrito; (e) o da natureza da justificação exigida; (f) o da medida de contribuição para a decisão. Vejamos, pois, cada um deles.

\section{$O$ critério da dissociação justificante ${ }^{63}$} implica um retorno ao paradigma anterior, eis que procura atestar que os princípios seriam os alicerces do ordenamento jurídico, em uma clara confusão de normas jurídicas e valores. Tudo o que já se disse sobre o tema, inclusive o fato de que normas tidas por regras também podem traduzir valores que estruturam o ordenamento jurídico. Pertinente, pois, a observação de Galuppo:

A confusão decorre do fato de que normas jurídicas podem desempenhar uma função axiológica (aquilo que é tido como o bem pela comunidade) e uma função deontológica (aquilo que é dever para a sociedade), ou seja, que as normas jurídicas, sendo uma prescrição

${ }^{62}$ Em sua obra, Ávila separa esses critérios. Contudo, como os entendemos de tal forma imbrincados, optamos por associá-los.

${ }^{63}$ De um lado, podem-se analisar os princípios de modo a exaltar os valores por eles protegidos, sem, no entanto, examinar quais são os comportamentos indispensáveis à realização desses valores e quais são os instrumentos metódicos essenciais à fundamentação controlável da sua aplicação. Nessa hipótese privilegia-se a proclamação da importância dos princípios, qualificando-os como alicerces ou pilares do ordenamento jurídico. Mais do que isso, pouco. De outro lado, pode-se investigar os princípios de maneira a privilegiar (...) as condutas necessárias á realização dos valores por lês prestigiados quanto justificar $e$ controlar sua aplicação mediante reconstrução racional dos encunciados doutrinários e das decisões judiciais. (ÁVILA, Teoria dos princípios, p. 56). 
de dever (sendo, portanto, intrinsecamente, operadores deontológicos), podem possuir ou conter também valores (possuindo, portanto, extrinsecamente, operadores axiológicos). ${ }^{64}$

\section{O critério da dissociação abstrata e}

heurística ${ }^{65}$ também não subsiste à crítica. Para ele, esse critério se daria no plano preliminar de análise abstrata das normas, anterior ao plano conclusivo de análise concreta das normas, eis que teria a utilidade de aliviar o ônus argumentativo para o aplicador do Direito. Essa distinção traria consigo apenas um modelo ou hipótese provisória de trabalho, sem qualquer pretensão de fixar uma fórmula dedutiva de fundamentação de decisões concretas.

A despeito de sua aparência lógica, esse critério acaba por representar também um retorno ao paradigma anterior, eis que, afinal de contas, qual seria o contrário para se fazer a distinção nesse "plano preliminar": generalidade, abstração, indeterminação tipológica? De outra banda, esse critério traz consigo também uma objetificação do texto legislativo, típico da filosofia da consciência. Ademais, não custa lembrar as próprias palavras de Ávila:

Normas não são textos nem o conjunto deles, mas os sentidos construídos a partir da interpretação sistemática de textos normativos. Daí se afirmar que os dispositivos se constituem no objeto da interpretação; e as normas, no seu resultado. O importante é que não existe correspondência entre norma e dispositivo, no sentido de que sempre que houver um dispositivo haverá uma norma, ou sempre que houver uma norma deverá haver um dispositivo que lhe sirva de suporte. Em alguns casos há norma mas não há dispositivo.

\footnotetext{
${ }^{64}$ GALUPPO, Igualdade e Diferença, p. 178.

${ }^{65}$ Cf. ÁVILA, Teoria dos princípios, ps. 57 e 60.
}

Quais são os dispositivos que prevêem os princípios da segurança jurídica e da certeza do Direito? Nenhum. Então há normas, mesmo sem dispositivos específicos que lhes dêem suporte físico. Em outros casos há dispositivo mas não há norma. Qual norma pode ser construída a partir do enunciado constitucional que prevê a proteção de Deus? Nenhuma. Então, há dispositivos a partir dos quais não é construída norma alguma. ${ }^{66}$

\section{O terceiro critério seria o da dissociação} em alternativas inclusivas, pelo qual seria admissível a coexistência de diferentes espécies normativas em um mesmo dispositivo, ou seja, um mesmo texto permitiria a construção de regras e princípios ${ }^{67}$. Assim, um texto estaria aberto para uma dimensão comportamental, típico das regras, e outro finalístico, característico dos princípios.

Ávila exemplifica seu raciocínio por meio do dispositivo que determina a exigência de lei em sentido formal para a instituição ou aumento de tributos. Como regra, tal dispositivo condicionaria a validade da criação ou majoração de tributos a uma procedimentalização ligada a um veículo legislativo determinado, a lei. Como princípio, o dispositivo estaria realizando os valores de confiança e segurança jurídica em favor do contribuinte.

O dispositivo constitucional segundo o qual se houver instituição ou aumento de tributos, então só podem ser abrangidos fatos geradores ocorridos apões o início da vigência da lei que os houver instituído ou aumentado, é aplicado como regra se o aplicador entendê-lo como mera exigência de publicação de lei antes da

${ }^{66}$ ÁVILA, Teoria dos princípios, p. 22.

${ }^{67}$ Ávila fala também na construção de postulados. Contudo, como o próprio não os vê como uma terceira espécie normativa, preferimos deixar o exame de postulados para o terceiro item desse capítulo. 
ocorrência do fato gerador do tributo, e pode ser aplicado como princípio se o aplicador concretizá-lo com a finalidade de realizar o valor segurança para proibir o aumento de tributo no meio do exercício financeiro em que a realização do fato gerador periódico já se iniciou, ou com o objetivo de realizar o valor confiança para proibir o aumento individual de alíquotas, quando o Poder Executivo publicou decreto anterior prometendo baixá-las. ${ }^{68}$

Adistinção acima retoma o problema central da teoria dos princípios de Alexy. Como vimos, ele cinde a operação hermenêutica em duas: quanto às regras, devemos operar de modo silogístico, mecânico e formalista; quanto aos princípios, o emprego pós-positivista de sua teoria da argumentação. Ávila simplesmente afirma que um mesmo dispositivo, ora deve receber um tratamento subsuntivo, ora deve ser submetido à ponderação de valores. Contudo, o problema em si de retorno à filosofia da consciência permanece.

Esse critério de Ávila se aproxima de uma dificuldade já percebida pelo próprio Dworkin quando da elaboração de sua teoria. Veja a observação de Eros Grau sobre o problema:

Dworkin anota, ainda, que algumas vezes uma regra e um princípio desempenham a mesma função e a diferença entre ambos se reduz quase que exclusivamente a uma questão formal. A Seção I da Lei Sherman declara nulos os contratos que restrinjam o comércio. A Suprema Corte teve de pronunciar-se a respeito do seguinte: essa disposição deve ser tomada como uma regra, em seus próprios termos (isto é, impugnação de todo contrato que restrinja o comércio, o que decorre de quase todos os contratos) (ou seja, pela fórmula do tudo ou nada), ou como um princípio que estabelece uma razão para que se impugne um contrato, na ausência

${ }^{68}$ ÁVILA, Teoria dos princípios, p. 34, sem destaque no original). de outras diretrizes efetivas que apontem o contrário? A Corte interpretou a disposição como regra, porém como se nela estivesse inserido o vocábulo "irrazoável" e, assim, ela somente proibisse a restrição "irrazoável" do comércio (Standard Oil y United States, 221 U.S.1,60 - 1911; United States y American Tobacco Co., 221 U.S. 106,180 - 1911). Isso aprestou a disposição a funcionar logicamente como regra (sempre que um tribunal entender que uma restrição é "irrazoável”, estará obrigado a declarar inválido o contrato), e, substancialmente, como princípio (o tribunal deve considerar uma variedade de outros princípios e diretrizes para decidir se uma determinada restrição, em circunstâncias econômicas específicas, é "irrazoável”). Daí porque - prossegue Dworkin - palavras como "razoável", "negligente", "injusto", "importante" (termos indeterminados por imprecisão [...]), fazem com que a regra na qual inseridas dependa, na sua aplicação, do quanto repouse, sob elas, de princípios ou diretrizes; a regra se assemelha, então, a um princípio. Mas ela não se transforma, em razão disso, em princípio, visto que a mais sutil limitação desses termos restringe a classe de outros princípios e diretrizes sobre os quais se apóia a regra. Se a regra diz que os contratos "irrazoáveis" são nulos ou que os contratos evidenciadamente "injustos" não devem ser executados, devemos avaliar a questão com atenção maior do que aquela que nos seria reclamada se esses termos nela não tivessem sido inseridos. ${ }^{69}$

Ora, a observação de Dworkin deixa antecipar que ele próprio percebe dificuldades para garantir a higidez de uma dicotomia normativa. Agora, entende que um mesmo dispositivo possa receber duplo tratamento, claro que em casos diferentes, em função da abertura natural de alguns termos, tais como 'razoável', 'justo', 'negligente' e outros. Contudo, cabe aqui uma pergunta:

${ }^{69}$ GRAU, A ordem econômica na Constituição de 1988, p. 111/112. 
isso significaria, por outro lado, a existência de termos ou expressões lingüísticas com univocidade de sentidos? Uma resposta afirmativa implicaria a desconstrução de toda a reviravolta lingüística-pragmática iniciada no século passado. Portanto, não vislumbramos sucesso para o critério da dissociação em alternativas inclusivas.

$\mathrm{O}$ quarto critério seria o da natureza do comportamento prescrito ${ }^{70}$. Agora a distinção caminha para o modo de prescrição de comportamentos. As regras estabeleceriam obrigações, permissões e proibições mediante a descrição de uma conduta, enquanto os princípios se limitariam a estabelecer um estado ideal de coisas a ser buscado (Idealzustand), ou seja, um fim que se aspira obter, gozar ou possuir em uma dada situação.

Mais uma vez o critério é insuficiente. Primeiro, porque, a nosso ver, esse "estado ideal de coisas", para que não caia em um patamar metafísico, somente pode ser interpretado como uma associação direta dos princípios a valores, como se as regras não tivessem também atrás de si valores. Depois, caberia a questão: será que o princípio do duplo grau de jurisdição não estabelece em si uma obrigação?

\section{O critério da natureza da justificação} exigida representa também um retorno aos patamares do paradigma anterior, ganhando apenas alguma sofisticação, eis que guarda notável semelhança ao que já analisamos na tese de Robert Summers. Veja:

No caso das regras, como há maior determinação do comportamento em razão do caráter descritivo ou definitório do enunciado prescritivo, o aplicador deve argumentar de modo a fundamentar uma

\footnotetext{
${ }^{70}$ ÁVILA, Teoria dos princípios, p. 63.
}

avaliação de correspondência da construção factual à descrição normativa e a finalidade que lhe dá suporte. A previsão sobre um estado futuro de coisas é imediatamente irrelevante. Daí se dizer que as regras possuem, em vez de um elemento finalístico, um elemento descritivo. Sendo facilmente demonstrável a correspondência, o ônus argumentativo é menor, na medida em que a descrição normativa serve, por si só, como justificação. Se a construção conceitual do fato, embora corresponda à construção conceitual da descrição normativa, não se adequar à finalidade que lhe dá suporte ou for superável por outras razões, o ônus argumentativo é muito maior. São os chamados casos difíceis. $^{71}$

Ávila procura fugir da distinção das espécies normativas no seu modo de aplicação - "tudo ou nada" para as regras e ponderação para os princípios - levando esse critério para o modo de justificação ${ }^{72}$. Contudo, os problemas aqui parecem se somar. Será possível aplicar o direito sem justificar essa aplicação? Depois de Heidegger e Gadamer, será que tais conceitos podem ser cindidos? Ademais, ao supor que as regras tenham uma maior determinação, ele não estaria retornando ao paradigma moderno? Por fim, e agora forte em Dworkin, será que existem casos difíceis?

\section{O último critério é o da medida de} contribuição para a decisão que, em síntese, sustenta que os princípios não têm a pretensão de gerar uma solução específica, mas tãosomente de colaborar, junto de outras razões, para a tomada de uma decisão. Já as regras, teriam a aspiração de gerar uma solução específica para o conflito entre as razões ${ }^{73}$.

${ }^{71}$ ÁVILA, Teoria dos princípios, p. 65, sem destaque no original.

${ }^{72}$ Cf. ÁVILA, Teoria dos princípios, p. 65.

${ }^{73} \mathrm{Cf}$. ÁVILA, Teoria dos princípios, p. 68. 
Também esse derradeiro critério logra passar por um crivo de racionalidade da hermenêutica contemporânea. Desde já, salta aos olhos que o pressuposto de tal critério é o de uma maior determinação da factie specie das regras, ou seja, um retorno aos padrões da visão moderna e, como tal, já superados. Contudo, ao colocar os princípios apenas como uma razão que se coloca ao lado de outras para "colaborar" na aplicação do Direito, Ávila resvala perigosamente o primeiro paradigma, pelo qual os princípios não eram considerados normas jurídicas.

Ademais, esse critério e outros não se dão conta de que não se concebe na atualidade uma aplicação do Direito no qual se aplique somente regras ou, de outro lado, uma decisão que aplique somente princípios. No momento em que há a aplicação não há como separar textos legislativos.

Dito isso, cremos que o esforço em torno de uma teoria dos princípios alicerçada sobre a ponderação de valores fica definitivamente sepultado. Contudo, fica ainda a advertência de Alexy: negar a dicotomia de espécies normativas implica necessariamente um retorno ao positivismo. Em seu sentir, apenas a teoria dos princípios permite explicar o modo pelo qual uma norma deixa de ser aplicada sem, contudo, que se reconheça sua invalidade. Será correta tal assertiva?

A partir de pressupostos apartados dos de Alexy, Streck, forte em Dworkin, considera indispensável a manutenção da distinção das espécies normativas. Observe:

A afirmação "atrás de cada regra há um princípio" acarreta importantes consequiências. Com efeito, não poderá haver colisão entre regra e princípio; logo, uma regra não pode prevalecer em face de um princípio (...). Se correta a tese de que por trás de cada regra há um princípio, então a afirmação de que, em determinados casos, a regra prevalece em face ao princípio, é uma contradição. A prevalência de regra em face de um princípio significa um retorno ao positivismo, além de independizar a regra de qualquer princípio, como se fosse um objeto dado (posto), que é exatamente o primado da concepção positivista do direito, em que não há espaço para os princípios. Isto implica a discricionariedade - característica do positivismo, cerne, aliás, das principais críticas feitas por Dworkin à Hart -, ficando, assim, a cargo do intérprete (no caso mais específico do juiz) a escolha das hipóteses em que uma regra é independente de um princípio e a hipótese em que a regra prevalecerá diante do princípio. ${ }^{74}$

Portanto, faz-se necessário um retorno a Dworkin para reexaminar seus pressupostos de taxionomia das espécies normativas, e se tal distinção tem apenas a pretensão de fixála. Para tanto, vamos nos valer do magnífico trabalho de Galuppo que procura reconstruir a visão de Dworkin.

Nesse sentido, aparentemente, a Escola habermasiana não se afasta da tese levantada por Streck. Contudo, assume uma leitura de Dworkin absolutamente afastada daquela realizada pelos adeptos da ponderação de valores, sejam puristas ou alternativos.

Galuppo desenvolve sua visão sobre a concepção de Dworkin a partir do conceito de Direito como Integridade, ou seja, um direito que se vincula às noções de imparcialidade (fairness) e de igualdade. O Direito que respeita a integridade pretende fornecer a "resposta correta" para cada caso concreto. É tal pretensão que confere "integridade" ao Direito.

Como visto, Dworkin sustenta que dois tipos de argumentos podem ser utilizados

\footnotetext{
74 STRECK, Jurisdição Constitucional no Brasil,
} p. 35 . 
teoricamente para a aplicação do Direito: "os de princípio"75 e "os de orientação política". Contudo, na prática, uma jurisdição só será legítima caso limite-se ao uso dos primeiros, eis que a fixação de políticas que revelam metas coletivas a serem alcançadas não são competência do Judiciário. Assim, quando Dworkin fala em "argumentos de princípio", ele está essencialmente preservando o caráter deontológico do Direito.

Desse modo, ao mencionar a dimensão de peso para os princípios, de certo Dworkin não se volta para uma perspectiva de aplicação axiológica do Direito, como pensava Alexy. De certo, o emprego da expressão ponderação se volta para a noção de reflexão reconhecendo que o ordenamento jurídico é constituído por dispositivos prima facie e que, como tais, podem excepcionar-se reciprocamente diante dos casos concretos.

Portanto, se tivermos em mente a exigência de Integridade do direito (que se cumpre, antes de mais nada, de forma interpretativa), os princípios devem ser concebidos como direitos decorrentes do pluralismo constitutivo das sociedades contemporâneas, que não podem ser nem enumerados previamente a uma situação específica, nem hierarquizados em qualquer circunstância, e que podem excepcionar a aplicação de outros direitos, vez que, não podendo permanecer em concorrência uns com os outros no caso concreto, (...). ${ }^{76}$

A tarefa hermenêutica não se liga a procurar e demonstrar quais os princípios concorrem para a solução de um caso e a

${ }^{75}$ Segundo Dworkin, um princípio é "um modelo (standard) que deve ser observado, não porque ele avançará ou assegurará uma situação econômica, política ou social julgada desejável, mas porque é uma exigência de justiça ou de imparcialidade (fairness) ou de qualquer outra dimensão da moralidade". (Galuppo, Igualdade e diferença, p. 185/186).

${ }^{76}$ GALUPPO, Igualdade e diferença, p. 189. forma de melhor hierarquizá-los de modo a prejudicar o menos possível àquele que for afastado. Ao inverso, o trabalho é precisar a solução mais adequada para as circunstâncias relevantes do caso concreto.

Desse modo, as razões ligadas ao emprego dos princípios são razões comparativas, eis que não há uma pré-seleção das condições e limites para sua aplicação, tal como se dá com as regras. Isso porque os princípios seriam fluidos/abstratos e necessitariam de um esforço discursivo-interpretativo para serem densificados ${ }^{77}$, aquilo que Günther denomina por 'senso de adequabilidade'.

A distinção entre regras e princípios não poderia se dar no campo da morfologia, como pensava Alexy, mas na sua aplicação, eis que o modelo kelseniano "se a é, b deve ser" seria uma estrutura tão-somente aplicável às regras. Estas

Requerem uma aplicação inequívoca que está ligada à presença do componente condicional 'se' em uma situação concreta [...]. (Ao contrário,) falamos em aplicar uma norma como princípio quando entramos em um procedimento argumentativo que nos obriga a considerar todas as características da situação e a pesar os pontos de vista normativos relevantes. ${ }^{78}$

A partir do conceito de princípio desenvolvido por Kohlberg em torno de uma teoria do desenvolvimento moral, os princípios não podem ser mais vistos como uma solução preconcebida (a priori), mas uma forma geral de ver as coisas. Dito de outro modo, ele deixa de lado qualquer perspectiva de distinção morfológica entre regras e princípios e vê os últimos como

\footnotetext{
${ }^{77}$ GÜNTHER, 1993:271 e 272.

${ }^{78}$ GALUPPO, Igualdade e Diferença, p. 191.
} 
uma forma de argumentação que não parte de posições já firmadas, eis que somente diante das situações concretas essa interpretação pode se dar. Assim, por exemplo, o valor da pessoa humana não é concebido como um padrão substancial aprioristicamente definido, mas como um meio de construir uma solução para um problema moral concreto ${ }^{79}$.

Em nossa opinião, na concepção pela qual Dworkin se afasta de uma aplicação axiológica do Direito, na sua exigência em torno dos argumentos de princípio para garantirem o código binário do Direito ${ }^{80}$ e seu conceito de Direito como Integridade ligada à noção de resposta correta e de imparcialidade, não merecem retoques.

Entretanto, a teoria de Dworkin conduz a duas formas de explicitar sua teoria dos princípios, muito bem descrita por Galuppo: a primeira que representa um esforço de distinguir espécies normativas e uma segunda que aborda a superação da hermenêutica positivista. Em nossa opinião, consideramos desnecessário qualquer esforço no sentido de explicitar uma distinção entre as espécies normativas como mecanismo de escaparmos do positivismo, eis que um exame crítico sobre os elementos que distinguiriam regras e princípios mostra-se, também aqui, como um empreendimento mal sucedido.

${ }^{79}$ Cf. KOHLBERG, Lawrence, Levine, Charles, Hewer, Alexander. La formulación actual de la teoria. In: Kolberg, Lawrence (org.). Psicologia del desarollo moral. Bilbao: Desclée De Brouwer, 1992, p. 221-312, p. 292.

${ }^{80} \mathrm{O}$ Direito aparece como um sistema normativamente fechado e cognitivamente aberto. Ele é fechado naquela função que não pode ser substituída, controlada nem dirigida por um outro sistema: a decisão a respeito da licitude e ilicitude (Recht und Unrecht). Com essa decisão pode marcar qualquer coisa, desde que, ao fazê-lo atenha-se tão-somente aos próprios pressupostos internos. (GÜNTHER, Teoria da argumentação, p. 381).
Alguns dos fundamentos dessa distinção representam também um retorno ao paradigma anterior. Senão vejamos. O primeiro problema já se dá quando Galuppo sustenta que os princípios garantiriam a abertura indispensável do ordenamento jurídico para o pluralismo marcante nas sociedades atuais. Contudo, fica a dúvida: por que apenas os princípios sustentam a abertura permanente da identidade do sujeito constitucional? Esse fenômeno não decorre da própria abertura lingüística e, então, comum a todo o ordenamento jurídico? Caso contrário haveríamos de considerar que os princípios teriam um grau de abstração maior do que as regras?

Ora, o aspecto da densidade normativa parece-nos algo já superado no contexto do debate atual ${ }^{81}$. Depois pretende também demonstrar ser possível marcar a distinção entre regras e princípios no plano da justificação, afirmando o caráter nomogenético dos mesmos, ou seja, seu caráter de fundamentabilidade do sistema jurídico, nos mesmos termos de Canotilho ${ }^{82}$. Tal assertiva conduz às seguintes questões: Qual o critério para atestar que uma norma prima facie seja tida por mais elevada em um ordenamento jurídico? Por que somente os princípios exigiriam razões comparativas e não as regras? Essa concepção parece indicar a concepção de que a aplicação das regras se daria de forma subsuntiva e que somente

${ }^{81}$ A despeito de nossa opinião, é forçoso observar que Habermas parece também acatar a concepção de jusfundamentalidade em sua obra. Veja: Princípios ou normas mais elevadas, em cuja luz outras normas podem ser justificadas, possuem um sentido deontológico, ao passo que os valores têm um sentido teleológico. (HABERMAS, Direito e Democracia, vol. I, p. 316).

${ }^{82}$ GALUPPO, Igualdade e diferença, p. 196/197. 
os princípios demandariam uma reflexão em sua aplicação. Ou, então, um retorno às concepções de Summers. Contudo, em uma hipótese ou em outra, como se livrar então do óbice da cisão hermenêutica?

Habermas não colabora para a resposta a tais questões, eis que assume sem maiores comentários a posição de Dworkin. Contudo, Günther, por sua vez, pretende lançar luzes sobre a questão anotando que a distinção das espécies normativas deveria ser encontrada na forma de argumentação. Veja:

A descrição de Alexy do comportamento de colisão, não obstante sugere a suposição de que a distinção de regras e princípios diz menos à estrutura de normas do que à sua aplicação em situações concretas, nas quais a aplicação imparcial de normas demanda a consideração de todos os sinais característicos. Possivelmente será mais fácil, em lugar disso, retomar a proposta de Searle de que a distinção, localizada por Alexy na estrutura da norma, poderá ser reconstruída de modo mais adequado em condições de conversação, sob as quais nos posicionamos diante de compromissos em determinada situação. Nesse caso, a diferença consistiria mais em tratarmos de uma norma como regra, à medida que a aplicarmos sem considerar os sinais característicos desiguais da situação, ou como princípio, à medida que a aplicarmos mediante o exame de todas as circunstâncias (efetivas jurídicas) em determinada situação. Os diferentes modos de tratamento se originam, portanto, do fato de que, no caso da aplicação da regra, as restrições institucionais e ponderações de adequação ficam excluídas e, no caso da aplicação de princípios, são admitidas. Uma vez que a exclusão de ponderações de adequação infringe o princípio da aplicação imparcial de normas, ela deveria ser justificada; por exemplo, no sentido de um conceito de justiça convencional, pelo motivo de a antecipação das ponderações de adequação ser vista como desconsideração do legislador político. O legislador já teria decidido a respeito da adequação de uma norma, no sentido da "moralidade do sistema social" (social system's morality), de modo que as violações somente seriam admissíveis em "casos excepcionais". Contudo, a estrutura da própria norma não seria afetada por esta distinção institucional. ${ }^{83}$

Günther afirma que as regras seriam fruto de uma argumentação excepcional no qual a aplicador poderia argumentar no sentido de desconsiderar as circunstâncias relevantes ao caso concreto para simplesmente confirmar as reflexões prévias do legislador político em um caso de aplicação de uma "justiça convencional". Contudo, sua tese parece-nos tampouco convincente. Está claro que ele se esforça para não retornar a padrões positivistas quando insiste que devemos fundamentar nossa desconsideração das circunstâncias concretas, ou seja, se o fazemos é porque "no fundo" não as estamos desconsiderando. Assim, o que devemos indagar é o que representa essa licença "para levar em conta as circunstâncias mas, ao mesmo tempo, desconsiderá-las no caso concreto"? O que ele entende por um retorno consciente para os padrões de uma justiça convencional?

Desde já afastamos a concepção de que possa ser uma autorização para uma aplicação subsuntiva/silogística diante do seu pungente esforço. Contudo, seria então o quê? O que poderia significar uma licença para um retorno excepcional para padrões de uma justiça convencional? Simplesmente não conseguimos resposta para essa situação limite concebida por Günther sem que com isso tenhamos, agora sim, uma recaída nos

${ }^{83}$ GÜNTHER, Teoria da argumentação, p. 315/316, sem destaque no original. 
padrões de uma filosofia da consciência. $\mathrm{E}$, isso se dá diante das seguintes indagações: ora, uma vez que alcançamos o patamar de uma justiça de padrões pós-convencionais por meio das conquistas do giro lingüístico, como é que poderíamos retornar a uma configuração convencional? De que modo o legislador poderia antecipar a forma de aplicação de uma norma sem que isso viole a hermenêutica como analítica existencial? Ora, se refletimos para afastar a consideração das circunstâncias específicas de um caso concreto, isso não implica dizer que as mesmas são irrelevantes e então de modo algum estaríamos nos afastando do princípio da aplicação imparcial de normas. Logo, sua tese não nos parece convincente para lograr demonstrar a cientificidade dessa distinção.

Assim, se Günther não obtém sucesso, é preciso também reconhecer que todas as tentativas de examinar uma taxionomia entre normas prima facie, incluindo aqui aspectos ligados à densidade normativa, grau de abstração, abertura conceitual, generalidade, jusfundamentalidade dentre outras, representam uma grave aporia na teoria de Dworkin, eis que admitem/ pressupõem aquilo que ele pretende afastar: uma diferenciação morfológica das espécies normativas.

Dessa maneira, a concepção dworkiana deve ser compreendida mais como a demonstração de um hiato entre, de um lado, uma hermenêutica positivista - o modelo de regras -, com traços de instrumentalização da linguagem típicos da filosofia da consciência, subsuntiva, silogística, mecânica, e, de outro, a hermenêutica contemporânea que incorpora todos os ganhos da viragem lingüística - o modelo de princípios. Eis aqui a grande contribuição de Dworkin!
Por conseguinte, essa contraposição entre o modelo de regras e de princípios, ao invés de promover uma busca de espécies normativas, deve ser compreendida no contexto de uma alteração paradigmática na própria hermenêutica que se aplica ao Direito, especialmente se lembrarmos a influência de Gadamer sobre o jusfilósofo americano.

Assim, Dworkin sustenta que a admissão do Direito como integridade implica a transformação da sociedade em uma forma especial de comunidade. Essa forma especial, a "comunidade de princípios" se caracteriza justamente por promover a autoridade moral no emprego do monopólio da força coercitiva estatal, evitando a parcialidade, a fraude, o favoritismo, o revanchismo e a corrupção oficial. Logo, essa comunidade não fica adstrita a um rol de direitos previamente catalogados, mas se abre à construção desse direito.

A integridade também contribui para a eficiência do direito no sentido que já assinalamos aqui. Se as pessoas aceitam que são governadas não apenas por regras explícitas, estabelecidas por decisões políticas tomadas no passado, mas por quaisquer outras regras que decorrem dos princípios que essas decisões pressupõem, então o conjunto de normas públicas reconhecidas pode expandirse e contrair-se organicamente, à medida que as pessoas se tornem mais sofisticadas em perceber e explorar aquilo que esses princípios exigem sob novas circunstâncias, sem a necessidade de um detalhamento da legislação ou da jurisprudência de cada um dos possíveis pontos de conflito. ${ }^{84}$

O modelo de princípios é um modelo hermenêutico e não uma forma de classificação de espécies normativas em que se distinguem

${ }^{84}$ DWORKIN, O Império do Direito, p. 229, sem destaque no original. 
princípios das regras. A nosso ver, seria mais consentâneo reconhecer que todo o ordenamento jurídico contém tão-somente normas prima facie vinculantes e, como tais, sempre dependentes do caso concreto para se tornarem uma norma jurídica definitiva. É, assim, na forma de aplicação do Direito, que subjaz a distinção preconizada por Dworkin e acatada por Günther ${ }^{85}$.

Em seu debate com o principal sucessor de Hart, Joseph Raz ${ }^{86}$, Dworkin já há longo tempo destacava que o ponto nevrálgico de sua teoria podia ser traduzido pela procura em se desvincular do esforço ontológico de estruturar morfologicamente distinções entre espécies normativas, mas confirma a idéia da necessidade de mudança na forma de concepção da aplicação do Direito que supere os limites do positivismo. Observe que:

\section{Raz parece pensar que o problema da individuação das leis (...) trata-se de um problema a respeito da estrutura formal do direito, que é importante para um filósofo do direito, mas não para o autor de um texto. (...) O meu ponto de vista não é que "o direito" contenha um número fixo de padrões, alguns dos quais são regras e outros, princípios. Na verdade quero opor-me à idéia de que "o direito" é um conjunto fixo de padrões de algum tipo. Ao contrário, o que enfatizeis foi que uma síntese acurada dos elementos que os juristas devem levar em consideração, ao decidirem um determinado}

${ }^{85}$ Para descobrir como argumentações de adequação condicionadas à dupla contingência podem tornarse possíveis, poderemos retomar a nossa sugestão de relacionar a distinção entre regras e princípios, apresentada no debate com Alexy, porém, de modo diferente, não com a estrutura da norma, mas com as condições de ação, sob as quais as normas são aplicadas. (GÜNTHER, Teoria da Argumentação, p. 391/392).

${ }^{86} \mathrm{Cf}$. RAZ, Joseph. Practical reason and norms. Oxford: Oxford University Press, 1975, p. 49. problema sobre deveres e direitos jurídicos, incluirá proposições com a forma e a força de princípios e que, quando justificam suas conclusões, os próprios juízes e juristas, com freqüência, usam proposições que devem ser entendidas dessa maneira. Nada disso, creio, compromete-me com uma ontologia jurídica que pressuponha qualquer teoria específica da individuação. ${ }^{87}$

Streck aproxima-se desse ponto central sem, contudo, alcançá-lo quando sustenta que atrás de cada regra é possível pensar-se em um princípio. No trecho que se segue, fica clara sua percepção de que a questão principiológica deve se voltar para uma ruptura paradigmática, com o que damos nossa adesão. Veja:

Numa palavra; a "abertura principiológica" deve ser examinada no contexto de ruptura paradigmática com o modelo subsuntivo. $\mathrm{O}$ positivismo colocou à disposição da comunidade jurídica o "direito como um sistema de regras". A conseqüência disso é que a "facticidade" (o mundo prático) ficava de fora (afinal, foram anos de predomínio do positivismo) ${ }^{88}$

Contudo, em seguida dá um passo atrás e procura ainda ver nos "princípios" o caráter hermenêutico, isso é, como se o mesmo fosse dependente dos princípios. Assim, é que ele vê uma aproximação de regras e princípios ou, melhor dizendo, entende ainda que os princípios estariam na/por detrás das regras em sua aplicação, vendo uma diferença essencial entre as espécies normativas, como se percebe abaixo:

Ora, a inserção da faticidade se dá através dos princípios, que, para ale, do causalismoexplicativo de caráter ôntico, vai se situar no

${ }^{87}$ DWORKIN, Levando os direitos a sério, p. 118/120, sem destaque no original.

${ }^{88}$ STRECK, Verdade e Consenso, p. 144. 
campo do acontecer de caráter ontológico (não clássico). Daí a questão de fundo para a compreensão do fenômeno: antes de estarem cindidos, há um acontecer que aproxima regra e princípio em duas dimensões, a partir de uma anterioridade, isto é, a condição de possibilidade da interpretação da regra é a existência do princípio instituidor. (...) Em síntese: há uma essencial diferença - e não separação - entre regra e princípio. Podemos até fazer a distinção pela via da relação sujeito-objeto, pela teoria do conhecimento. Entretanto, essa distinção será apenas de grau, de intensidade; não será, entretanto, uma distinção de base entre regra e princípio. ${ }^{89}$

Entretanto, além de entendermos, como já se viu acima, que as distinções na relação sujeito-objeto são metafísicas, há que se indagar também: por que as regras dependem dos princípios para que se dê o acontecer hermenêutico? Ou, por que a faticidade é dependente dos princípios? Em termos gadamerianos, em que os princípios como textos/eventos que são se distinguem das regras? Ou seja, desde quando Gadamer entende que os princípios sejam uma "muleta" para a fusão de horizontes e para a concepção de que toda interpretação é uma aplicação?

Assim, a Escola Hermenêutica não se dá conta de que não há uma "essencial diferença" entre as espécies normativas para que a interpretação se dê em bases pós-positivistas simplesmente porque são todas elas textos normativos. Claro que na aplicação do Direito, mais de um mandado prima facie será aplicado, mas isso não confere aos princípios uma condição especial, pois até onde compreendíamos Gadamer não são os princípios que garantem o

${ }^{89}$ STRECK, Verdade e Consenso, p. 167/168, sem destaque no original. acontecer hermenêutico e sim a própria "ek-sistência" do homem. Dizer o inverso é, de um lado, buscar metafisicamente uma distinção na leitura pura e simples de textos legislativos, dando primazia a um 'universal' (princípio) na interpretação sobre outro (regra), e, de outro, não se dar conta que a fusão hermenêutica atribuidora de sentido à norma/decisão tampouco permite a cisão de tais figuras nos textos empregados nessa operação. $\mathrm{Ou}$, se permite, até então não há uma teoria normoteorética que nos convença de sua racionalidade. Isso porque, desde Gadamer, a norma só passa a existir com sua aplicação ${ }^{90}$.

Nem a hermenêutica nem tampouco a teoria do discurso devem suportar essa dicotomia de espécies normativas e, sim, alardear uma mudança no paradigma da interpretação como um todo, pois fora de uma visão em torno da ponderação de valores, qual a utilidade de separar regras e princípios nos parâmetros atuais de nossa racionalidade? Negar uma distinção ontológica entre as espécies normativas implicaria a quadra

${ }^{90}$ (...) a tese da indeterminação estrutural (de espécies normativas) pelo entendimento hermenêutico de que não conseguimos compreender um texto, independentemente da sua situação de interpretação, foi radicalizada pela afirmação de que cada norma em si só passará a ser uma norma determinada no próprio ato da interpretação. Se experiências futuras não podem ser antecipadas, uma norma apenas obtém a sua validade obrigatória na respectiva situação de interpretação. É isso que está indicado na conhecida imagem de Engisch a respeito do "olhar que corre para lá e para cá", entre preceito principal e realidade factual de vivência. Esta metáfora motivou a se considerar a relação entre norma e realidade factual como u círculo, uma vez que a norma indeterminada somente será definida pela realidade factual, e a realidade factual, pela norma nos seus sinais característicos relevantes. (GÜNTHER, Teoria da Argumentação, p. 398). 
atual do pensamento jurídico um retrocesso ao positivismo? Cremos sinceramente que não, eis que o essencial é construir uma ‘argumentação de princípios', ou seja, calcada na filosofia da linguagem, concretista e aberta, livre, pois, dos padrões formalistas e subsuntivos do positivismo e da filosofia da consciência.

Desse modo, o emprego de uma nomenclatura específica de regras e princípios parece-nos ligada às tradições, aos usos e hábitos jurídicos formados há mais de cem anos. Logo, não se espera que esses costumes desapareçam de imediato e nem em um horizonte curto de tempo. Ademais, se o trabalho de Dworkin teve o papel de questionar o positivismo, certamente sua utilidade permanece muito viva em um país cujo modo de operação do Direito continua predominantemente ligado ao século XIX.

Entretanto, é preciso deixar claro que podemos continuar a empregar essa nomenclatura, sem, contudo, reconhecer sua utilidade ou sua cientificidade. Desse modo, não vejo razão para deixarmos de designar o caput do artigo $5^{\circ}$ da Constituição vigente como "princípio da igualdade". O papel platônico de didascalion da linguagem, qual seja, de que ela poderia/deveria classificar os seres no mundo, cremos já está superada. Assim, não pretendemos aqui uma revolução pela proibição do emprego dessa ou daquela terminologia. O objetivo deste trabalho passa muito longe de uma tal arrogância. Ao contrário, queremos apenas demonstrar a necessidade constante de pensar o Direito e de nunca assumirmos uma posição de reprodução do conhecimento. Um marco teórico não pode jamais ser compreendido como uma amarra, eis que o respeito acrítico a dogmas contraria a liberdade de pensamento. Ao contrário, deve permitir a todo aquele que pretende "pensar o Direito" instrumentos para ultrapassá-lo!

Ficamos, pois, tal qual São Tomé, à espera de que alguém formule um critério que nos convença da racionalidade/utilidade de tal distinção, mas que o faça dentro da aplicação do direito e que não promova uma cisão da ontologia hermenêutica. Dessa forma, repudiamos desde já uma postura preguiçosa e estática de simplesmente rejeitar nossas objeções e confirmar a distinção sem se preocupar com a demonstração de uma base racional para sustentá-la. Assim, não podemos mais tolerar que os operadores do direito procedam tal como a sociedade o faz em relação às suas crendices, o que pode ser sintetizado no conhecido adágio: "Não acredito em bruxas, mas que elas existem, existem...."

\section{REFERÊNCIAS}

AFONSO DA SILVA, Luís Virgílio.

O proporcional e o razoável. Revista dos tribunais, n. ${ }^{\circ}$ 798, ano 91, p. 23-50, abr. 2002.

AFONSO DA SILVA, Luís Virgílio. Princípios e regras: mitos e equívocos acerca de uma distinção. Belo Horizonte: Del Rey, Revista Latino Americana de Estudos constitucionais, p. 607-628.

ALEINIKOFF, Alexander. Constitutional law in the age of balancing. The Yale Law Journal, vol. 96, n. ${ }^{\circ} 05$, abr. 1987.

ALEXY, Robert. Teoria de los derechos fundamentales. Madrid: Centro de Estúdios Constitucionales, 1997.

ALEXY, Robert. Direitos constitucionais, balanceamento e racionalidade.in Ratio Júris, vol. 16, n. ${ }^{\circ}$ 2, junho de 2003. Tradução para fins acadêmicos por Menelick Carvalho Netto, p. 01-10. 
ALEXY, Robert. Derecho y razón prática. México: Distribuiciones Fontamara, 1993.

ATALIBA, Geraldo. República e Constituição. São Paulo: Revista dos tribunais, 1985.

ÁVILA, Humberto. Teoria dos princípios. Da definição à aplicação dos princípios jurídicos. $2^{a}$ edição. São Paulo: Malheiros, 2003.

BACHOF, Otto. Normas constitucionais inconstitucionais. Tradução de José Manuel M. Cardoso da Costa.Coimbra: Almedina, 1994.

BARCELLOS, Ana Paula de; Barroso, Luís Roberto. O começo da história: a nova interpretação constitucional e o papel dos princípios no Direito Brasileiro. Afonso da Silva, Luís Virgílio (organizador). Interpretação constitucional. São Paulo: Malheiros, 2005.

BARCELLOS, Ana Paula. A eficácia jurídica dos princípios constitucionais: o princípio da dignidade da pessoa humana. Rio de Janeiro: Renovar, 2002.

BOULANGER, Jean. Principes géneraux du droit positif et droit positif. In Le Droit Privé Français au milieu du XX $X^{e}$ siècle (Études offertes a Georges Ripert). Paris: LGDJ, 1950.

CANARIS, Claus-Wilhelm. Pensamento sistemático e conceito de sistema na ciência do Direito. 3. ed. Introdução e tradução de A. Menezes Cordeiro. Lisboa: Fundação Calouste Gulbekian, 2002.

CANOTILHO, J.J. Gomes. Direito constitucional e Teoria da Constituição. Coimbra; Almedina, 1997.

CANOTILHO, José Joaquim Gomes. Direito Constitucional. 4. ed. Coimbra; Almedina, 1992.

CARVALHO NETO, Menelick. Hermenêutica Constitucional sob o paradigma do Estado Democrático de Direito, p. 25/44.

CRISAFULLI, Vechio. Per la determinazione Del conetto dei principi generali Del Diritto. In Revista Internazionale de Filosofia Del Diritto, v. XIX.Ano XXI, série II, jan. abr. de 1941.

CRUZ, Álvaro Ricardo de Souza. Jurisdição Constitucional Democrática. Belo Horizonte: Del Rey, 2004.
DWORKIN, Ronald. Levando os direitos a sério. São Paulo: Martins Fontes, 2002.

DWORKIN, Ronald. Response to overseas commentators. I.CON, vol 1, número 4, p. 651-662, 2003.

DWORKIN, Ronald. O Império do Direito. Tradução de Jefferson Luiz Camargo. São Paulo: Martins Fontes, 1999.

DWORKIN, Ronald. Uma questão de princípio. Tradução de Luís Carlos Borges. São Paulo: Martins Fontes, 2001.

ESSER, Josef. Princípio y norma en la elaboración jurisprudencial Del Derecho Privado. Tradução de Eduardo Valenti Fiol. Barcelona: Bosch, 1961.

GALUPPO, Marcelo. Igualdade e Diferença. Belo Horizonte: Mandamentos, 2002.

GALUPPO, Marcelo. A contribuição de Esser para a reconstrução do conceito de princípios jurídicos. Belo Horizonte: Editora da Faculdade de Direito da UFMG: Revista de Direito Comparado, n. 03, maio/1999, P. 227/244.

GRAU, Eros. A ordem econômica na constituição de 1988 (interpretação e crítica). 2. ed. São Paulo: Revista dos tribunais, 1991. GÜNTHER, Klaus. Teoria da Argumentação no direito e na moral: justificação e aplicação. Trad. Cláudio Molz. São Paulo: Landy, 2004.

HAGE, Jaap. C. Reasoning with rules. An essay on legal reasoning and its underlying logic. Dordrecht: Kluwer, 1997.

KELSEN, Hans. Teoria Pura do Direito. Tradução de João Baptista Machado. 4. ed. Coimbra: Armênio Amado, 1979.

KOHLBERG, Lawrence, Levine, Charles, Hewer, Alexander. La formulación actual de la teoria. In: Kolberg, Lawrence (Org.). Psicologia del desarollo moral. Bilbao: Desclée De Brouwer, 1992.

LARENZ, Karl. Metodologia da Ciência do Direito. Tradução de José Lamego. 3. ed. Lisboa: Fundação Calouste Gulbekian, 1997. 
MELLO, Celso Antônio Bandeira de. Elementos de Direito Administrativo. São Paulo: Revista dos tribunais, 1980.

MEYER, Emílio Peluso Neder. As sentenças intermediárias no marco de uma compreensão constitucionalmente adequada do controle jurisdicional de constitucionalidade ao paradigma procedimentalista do Estado Democrático de Direito. Dissertação de mestrado junto à Faculdade de Direito da UFMG, defendida em 17 de maio de 2006.

RAZ, Joseph. Practical reason and norms. Oxford: Oxford University Press, 1975.

REALE, Miguel. Lições Preliminares de Direito. São Paulo: Saraiva, 1988.
SILVA, Antônio Henrique Corrêa. Colisão de princípios e ponderação de interesses: solução ruim para problema inexistente. Rio de Janeiro: manuscrito, 2002, p, 01-23.

STRECK, Lenio Luiz. Jurisdição Constitucional no Brasil. : a resposta hermenêutica às críticas da teoria do discurso habermasiana. In Cruz, Álvaro Ricardo de Souza Cruz (org.). A teoria discursiva do Direito em debate. São Paulo: Landy, 2007.

STRECK, Lenio Luiz. Verdade e Consenso. Rio de Janeiro: Lumen Juris, 2006.

SUMMERS, Robert. Two types of substantive reasons: the core of a theory of common law justification. In The Jurisprudence of Law's Form and Substance (Collected Essays in Law). Alderhot, Ashgate, 2000. 
